\title{
How Entrenchment, Incentives and Governance Influence REIT Capital Structure
}

\author{
Chinmoy Ghosh • Erasmo Giambona • \\ John P. Harding • C. F. Sirmans
}

Published online: 23 March 2010

(C) The Author(s) 2010. This article is published with open access at Springerlink.com

\begin{abstract}
Although recent literature has confirmed the importance of viewing a firm's capital structure choices of leverage and debt maturity as jointly determined, to date there has been little analysis of the importance of traditional governance variables on a firm's capital structure decisions using a simultaneous equations approach. We examine the influence of managerial incentives, traditional managerial monitoring mechanisms and managerial entrenchment on the capital structure of Real Estate Investment Trusts (REITs). Using panel data, we estimate a system of simultaneous equations for leverage and maturity and find that firms with entrenched CEOs use less leverage and shorter maturity debt. This is consistent with the expectation that managers acting in their own self interest will choose lower leverage to reduce liquidity risk and use short maturity debt to preserve their ability to enhance their compensation and reputations by empire building. We also find evidence that traditional alignment mechanisms such as equity and option ownership have an offsetting effect; and that firms where the founder serves as CEO choose higher leverage and longer maturity debt. The results also provide evidence that leverage and maturity are substitutes, firms with high profitability and growth opportunities use less leverage and firms with liquid assets use more leverage and longer maturity debt.
\end{abstract}

C. Ghosh · J. P. Harding $(\bowtie)$

University of Connecticut, 2100 Hillside Road, Storrs, CT 06269-1041, USA

e-mail: johnh@business.uconn.edu

C. Ghosh

e-mail: chinmoy.ghosh@business.uconn.edu

E. Giambona

University of Amsterdam, Roetersstraat 11, 1018 WB, Amsterdam, The Netherlands

e-mail: e.giambona@uva.nl

\section{F. Sirmans}

The Harold J. and Barbara W. Chastain, Eminent Scholar in Real Estate and Business Law, Florida State University, 821 Academic Way, Tallahassee, FL 32306, USA

e-mail: cfsirmans@cob.fsu.edu 
Keywords Entrenchment - Managerial incentives · Corporate governance · Capital structure $\cdot$ REIT

\section{JEL Classification G32}

\section{Introduction}

The importance of research on corporate governance has its roots in the work of Jensen and Meckling (1976) who pointed out the potential for significant agency costs when the ownership and control of a firm are separated. Among the agency problems discussed by Jensen and Meckling is the tendency for managers to consume excess perquisites and to undertake expansion of the firm to enhance their reputations and compensation (empire building). Subsequent researchers have studied various governance mechanisms including, for example, management compensation programs and board monitoring structures that could be used to limit the agency costs identified by Jensen and Meckling (1976). Another important governance mechanism for dealing with these agency problems is the design of the capital structure. ${ }^{1}$ For example, Datta et al. (2005) show that the use of short-term debt can serve as a valuable management monitoring mechanism limiting the overconsumption of perquisites while Hart and Moore (1995) show that long-term debt can be an effective deterrent to empire building. However, many of these standard capital structure prescriptions are silent about how to implement the optimal capital structure when the implementation depends on the very same management the structure is designed to control. Influential managers acting in their own selfinterest may choose a capital structure that differs from that desired by absentee owners.

The use of debt to deal with the agency problems identified by Jensen and Meckling (1976) is not costless; it creates two additional types of agency problems: 1) conflicts of interest between shareholders and debtholders and 2) conflicts of interest between shareholders and managers. The costs associated with the first type of agency problem are well documented in the literature. For example, Myers (1977) emphasized the potential for underinvestment resulting from the use of high leverage and long-term debt (debt overhang) because managers and shareholders may decide to forego positive net present value (NPV) projects when a portion of the benefits of the investment would accrue to the debtholders. ${ }^{2}$ The second agency problem arises when the optimal capital structure from the shareholder's perspective differs from the optimal capital structure from the manager's perspective. The owners may want to increase leverage to maximize tax benefits and limit free cash flow available to the managers. However, from management's perspective, the loss of free cash flow might reduce their overall compensation and also introduces the risk of bankruptcy and the loss of reputation and jobs. (See Fama 1980, for further discussion.) In such a case,

\footnotetext{
${ }^{1}$ For examples, see Grossman and Hart (1982), Stulz (1990), and Hart and Moore (1995).

2 Stiglitz and Weiss (1981) extend the rationale for underinvestment when a firm uses debt financing, claiming that, because bondholders do not know, ex-ante, the quality of the investments that managers and shareholders will choose, they infer adverse selection and demand a higher risk premium. The resulting higher cost of borrowing results in foregone profitable projects.
} 
managers may desire a lower level of leverage or different maturity structure than do the owners. ${ }^{3}$ The resulting capital structure reflects a compromise between managers and owners. That compromise is influenced by the relative power (entrenchment) of the managers and by the effectiveness of the monitoring, control and alignment mechanisms put in place by the shareholders. Consequently, a firm's observed capital structure is influenced by the owners' objectives, the entrenchment and power of managers, the existing governance mechanisms as well as the normal financial variables that have been typically used to explain capital structure.

As researchers have begun to investigate the interaction between existing governance mechanisms, managerial incentives and the firm's capital structure, most research has focused narrowly on how management entrenchment and existing corporate governance mechanisms influence a single capital structure attribute (e.g., leverage or maturity) or how a small subset of these factors (e.g., management ownership) influence the joint choice of leverage and maturity. For example, Berger et al. (1997) study how selected corporate governance measures, managerial incentives and management entrenchment affect a firm's leverage choice and Benmelech (2006) studies the impact of governance and entrenchment on a firm's choice of debt maturity. Datta et al. (2005) and Jiraporn and Kitsabunnarat (2008) estimate a simultaneous system of equations for leverage and maturity, but focus exclusively on the maturity choice and consider only a limited number of governance variables. For example, Datta et al. (2005) only study the impact of managerial ownership on debt maturity while Jiraporn and Kitsabunnarat (2008) use the Investor Responsibility Research Center (IRRC) Governance Index, a single summary measure of twenty-four different governance provisions. None of these papers has fully explained how individual governance mechanisms influence the capital structure using a simultaneous equation approach to jointly model leverage and maturity.

Barclay et al. (2003) provide the theoretical basis for the importance of modeling the simultaneity of firm's capital structure decisions. Their theoretical development shows that leverage and maturity are "substitutes" which means that managers can "game" the system by offsetting the effect of high leverage on personal welfare by making a suboptimal choice (from the shareholders' perspective) of maturity. For example, if managers are pressed by shareholders to undertake more leverage (and the resulting risk of default and liquidation) than they would individually prefer, they can partially preserve their ability to pursue empire building by keeping the maturity of the debt short. ${ }^{4}$ In this paper, we estimate the full capital structure decision using a simultaneous equation system for leverage and maturity while including a full complement of governance and entrenchment measures in the set of independent variables.

\footnotetext{
${ }^{3}$ In other circumstances, management may want to increase leverage above the level deemed to be optimal by owners. For example, in the absence of sufficient free cash flow, management may want to use debt financing to pursue empire building. Stulz (1988) and Harris and Raviv (1988) suggest that managers with significant ownership could seek to increase firm leverage above the optimal level in order to increase their voting power and minimize their termination risk from takeovers. In these models, managers use leverage strategically to build up entrenchment. Such strategic behavior requires the firm to be vulnerable to takeover and/or management to have a very significant ownership stake. A common theme in these studies is that there can be disagreement between managers and owners with respect to the optimal capital structure.

${ }^{4}$ Hart and Moore (1995) show how short-term debt can facilitate managerial empire building. We provide an example to elucidate their argument in the literature review section.
} 
We use a sample of Real Estate Investment Trusts (REITs) to study the capital structure decision and the relationship between capital structure and existing governance mechanisms. Although limiting the sample to a single industry has the drawback of making it harder to establish the generality of the findings, we believe that for this study, there are a number of offsetting benefits. One reason for focusing on REITs is that Benmelech (2005), Benmelech et al. (2005) and Giambona et al. (2008) have shown that asset liquidation value is an often overlooked significant determinant of a firm's capital structure and that there are good proxies for asset liquidation value available for REITs. ${ }^{5}$ Furthermore, REITs are well-suited for the study of agency issues related to capital structure because their tax-advantaged status, high required dividend payout, and uniform asset regulation eliminate or reduce the need to control for potentially confounding effects such as tax considerations or variations in dividend payout rates. ${ }^{6}$ Previous studies that have used REITs to study corporate finance issues include Gentry et al. (2003), Ling and Ryngaert (1997), Damodaran and Liu (1993), Wang et al. (1992), Jaffe (1991), Shilling and Howe (1988), and Allen and Sirmans (1987).

The results presented here provide new insight into the interaction between management entrenchment, managerial incentives, corporate governance and management's capital structure choices. This paper fills a gap in the literature by controlling for the simultaneity of the firm's choice of leverage and maturity while at the same time incorporating the potential influence of a large number of governance variables measuring managerial entrenchment, managerial financial incentives and internal corporate governance mechanisms. Specifically, we estimate a simultaneous equation system for leverage and debt maturity choices by REITs between 1997 and 2006. The results confirm previous findings with respect to the traditional financial influences on capital structure (e.g., that very profitable firms and firms with significant growth opportunities use less leverage) and the previous research on the effects of liquidation value (e.g., that firms with liquid, redeployable assets use higher leverage). With respect to the governance influences, we find a negative and significant relationship between measures of CEO entrenchment and both leverage and debt maturity. We find an offsetting positive relationship between CEO equity ownership and leverage and a positive relationship between an indicator that the CEO is the firm founder and debt maturity.

The paper is organized as follows: the next section discusses previous literature that provides the theoretical basis for our findings and previous empirical studies related to ours. The section following that discusses the model specification, the variables used and the data. The estimation results and robustness checks are discussed in the following two sections. The last section provides a brief summary and discussion of our main conclusions.

\footnotetext{
${ }^{5}$ Shleifer and Vishny (1992) develop the underlying theory that predicts firms with assets that retain their value in financial distress and can be easily redeployed will use higher leverage and longer maturity debt. They argue that market forces will lead to lead to an industry equilibrium that varies from industry to industry and depends on the correlation of firm profitability within the industry.

${ }^{6}$ As long as a REIT adheres to certain rules, it generally can avoid taxation at the corporate level. Those rules include the requirement that at least $75 \%$ of a REIT's assets must be in the form of real estate-related assets (basically real property or mortgages secured by real property), cash and government securities and the requirement to payout $90 \%$ of pre-tax net income (prior to 2001 , the requirement was $95 \%$ ).
} 


\section{Recent Literature on Corporate Governance and Capital Structure}

Since Barclay et al. (2003) and Johnson (2003), the importance of using a simultaneous system of equations to model the two major components of a firm's capital structure has been well-established. Both of these studies find strong, statistically significant, roles for leverage and maturity in the system of equations. ${ }^{7}$ However, neither study considered the possible effects of agency conflicts or existing governance mechanisms on the capital structure. Barclay, Marx and Smith focused on the effect of growth opportunities in capital structure decisions and Johnson (2003) extended that work to test the prediction of Myers (1977) and Hart and Moore (1995) that short-maturity debt can mitigate the negative effect of high growth opportunities on leverage. ${ }^{8}$ Giambona et al. (2008) used an approach similar to Johnson's to study the role of asset liquidation value. Shleifer and Vishny (1992) predicted firms with assets that retain their value in financial distress and can be easily redeployed will use higher leverage and longer maturity debt. Giambona et al. (2008) use a panel sample of REITs and report that between 1997 and 2003 firms with more liquid and redeployable assets used higher leverage and longer maturity debt than their peers with less liquid assets. However, like Barclay et al. (2003) and Johnson (2003), Giambona et al. (2008) do not control for the influence of agency problems or governance.

Berger et al. (1997) studied the effect of managerial entrenchment, managerial incentives and corporate governance on a firm's choice of leverage in a single equation model. The authors included CEO tenure, CEO ownership of stock and options and various measures of board influence and monitoring as well as the standard financial control variables (e.g., growth opportunities, firm size, etc.). Their single equation model provides support for the contention that entrenched CEOs choose lower leverage but also provides evidence that leverage increases with managerial stock ownership and option holdings, ceteris paribus. This latter result supports the view that aligned managers recognize the benefits of leverage (both tax and monitoring) and, because of their ownership interest, believe its benefits outweigh the personal liquidity and free cash flow costs. However, in light of the potential tradeoff between debt maturity and leverage, their model does not provide a complete picture of the overall influence of entrenched managers on the firm's capital structure.

Benmelech (2006) also provides a single equation analysis, but focuses exclusively on the choice of debt maturity. He analyzes the relationship between CEO entrenchment and governance and the choice of debt maturity. If a project financed with long term debt declines in value, but can still service the interest payments, managers have a personal incentive to defer shutting the project down

\footnotetext{
${ }^{7}$ Although neither Barclay et al. (2003) nor Johnson (2003) finds empirical support for the substitution theory, after controlling for asset liquidation value, Giambona et al. (2008) provide empirical evidence consistent with that Barclay, Marx and Smith prediction. Our results confirm the findings of Giambona et al. (2008) using a larger database.

${ }^{8}$ The notion that firms with high growth opportunities will use lower leverage is based on the original work of Myers (1977) and the underinvestment problem associated with financing using risky debt. The basic idea is that when a firm has a significant amount of long-term debt, shareholders have less incentive to undertake new firm value maximizing growth opportunities because a portion of the benefits of the investment will go to the existing debtholders by making their investment less risky. Theoretically, if those firms used short-term debt that matured before the new investment was made, then the underinvestment problem would be eliminated or at least reduced.
} 
early. Benmelech (2006) argues that the use of short term debt to finance projects transfers control over the decision to terminate a project from the managers to the debtholders. With short term debt, if the project value declines, the maturing debt cannot be rolled over and the creditors can shut the project down. To avoid this loss of control, Benmelech (2006) argues that managers will prefer to finance such investments with longer term debt while owners would prefer short maturity debt. Using a cross section of industrial firms, he finds a positive correlation between debt maturity and measures of entrenchment and weak governance. ${ }^{9}$ However, significantly, his model does not recognize the endogeneity of leverage and debt maturity and the possible substitution effect between them. For example, managers who desire to retain absolute control of the continuation decision may be better able to achieve that objective by reducing leverage than extending the maturity of debt. Benmelech (2006) emphasizes one particular decision - the decision to discontinue or abandon a project.

Hart and Moore (1995) argue the exact opposite point of view when they focus on a similar decision - the decision to undertake a new project. ${ }^{10}$ They argue that, conditional on the use of debt financing to undertake a long-term project, managers may prefer to use short-term financing in order to preserve the flexibility to use those "assets in place" to fund a future negative NPV project and that only long-term debt is effective in limiting the ability of managers to empire build by financing new projects based on assets in place.

To gain an intuitive appreciation for the important effect of debt maturity on management's ability to use assets in place to finance negative NPV projects, consider the following example. ${ }^{11}$ Assume a firm's assets comprise a single twoperiod project, $\mathrm{P}$ with time 2 possible future payoffs: $\$ 132.24$ in the good state and $\$ 65$ in the bad state. The $t=0$ cost (and market value using a $10 \%$ discount rate) of

\footnotetext{
${ }^{9}$ A number of other papers have argued that short-maturity debt is more effective than long-maturity debt in mitigating the under-investment problem created by the use of debt (See Marchica 2005, for further discussion.) However, these earlier studies did not consider the effect of choosing leverage and maturity at the same time.

${ }^{10}$ These two decisions reflect different aspects of the overinvestment, or empire building, problem. By postponing a decision to terminate a project, managers prevent the size of the firm from declining. By undertaking a negative net present value project, the managers increase the size of the firm. In both cases, the shareholders wealth would be maximized by returning the invested capital for redeployment elsewhere.

${ }^{11}$ To simplify the discussion, the example presented here is based on the use of secured (i.e., mortgage) debt. Hart and Moore's (1995) results do not depend on the use of secured debt and apply more generally to corporate debt; what is needed to trigger their results is that the corporate debt contain covenants forbidding the management to pledge the firm's assets to future lenders, which could be achieved with "negative" pledge agreements (Billet et al. 2007, report that about 44\% of all debt issuances in their Fixed Investment Securities Database sample contain negative pledge restrictions). Hart and Moore (1995) use a two period framework with assets in place at $\mathrm{t}=0$ and the possibility of new investment at $\mathrm{t}=1$. The firm's debt structure (mix of 1 year and 2 year debt) must be set at $t=0$. The payoffs to both the current assets and the potential new investment are stochastic at $\mathrm{t}=0$. Hart and Moore (1995) show that when the new project cannot be funded from free cash flow and early liquidation of the firm's assets is never justified at $t=1$, the optimal debt structure (i.e., the firm-value maximizing choice) entails setting one-year debt (short maturity) to zero and using all two-year debt. Their critical assumption about limited free cash flow is especially appropriate for REITs because of their dividend payout requirement. The example presented here is not intended to reflect the full Hart and Moore (1995) development but only to provide intuition about the use of assets in place to fund negative NPV projects.
} 
this project is $\$ 100 .{ }^{12}$ The asset payoffs are displayed in Panel A of Fig. 1 using a standard binomial lattice to describe future uncertainty. Although the payoffs to the project will be received at time 2 , information is received at time 1 that reveals whether the good or bad payoff will be received. Given a constant riskless rate of $4.5 \%$, after receiving the $\mathrm{t}=1$ signal, the market value of the project will be $\$ 126.55$ if good information is received or $\$ 62.20$ if the bad signal is received. The firm finances the $\$ 100$ acquisition cost with the sale of $\$ 70$ (net proceeds) of zero coupon risky debt and $\$ 25$ of equity. Given the parameters of the lattice, the equilibrium interest rate on the risky debt is $8.5 \%{ }^{13}$

Assume now that at $\mathrm{t}=1$, the managers of the firm have an opportunity to undertake a new, one-year, project. While the new project would expand the firm size and enhance the prestige, reputation and compensation of the managers, from the perspective of the shareholders, it is a negative NPV project because it has a cost of $\$ 25$ and a market value of only $\$ 20$ (with a certain time 2 payoff of \$20.9). Neither the current shareholders nor prospective new investors would finance this undertaking based solely on its merits. However, by using short term debt to finance the original asset acquisition, the firm's managers can use "assets in place" in the good state to undertake the negative NPV project.

To see how the original debt maturity choice influences management's ability to undertake the time 1 project, consider the description of the firm's borrowing capacity provided in Panel B of Fig. 1. First, we assume that the market participants limit their risk by requiring over collateralization and are willing to lend a maximum of $70 \%$ of the market value of assets pledged. Consider the case where the original debt issue had a maturity of 2 years. At time 1 , if the favorable signal is received, the pledged collateral increases in value to $\$ 126.55$ and the debt becomes premium riskless debt. However, if the bad signal is received, the market value of the pledged assets declines to $\$ 62$ and default at time 2 is certain. ${ }^{14}$ In both states of the world, however, the existing assets of the firm are not available to be pledged as security for another borrowing and so the firm's borrowing capacity at time 1 is based strictly on the market value of the new project $-\$ 14$. This amount is insufficient to finance the acquisition cost of $\$ 25$ and managers would be unable to undertake the new project.

Next, consider the case where the firm uses short maturity (one-year) debt to finance the original project at time 0 . If the good signal is received, the firm has $\$ 126.55$ market value of assets in place and $\$ 20$ of assets from the new project for a total of available collateral of $\$ 146.55$. Using the $70 \%$ collateral requirement, the firm could borrow $\$ 102.58$. This amount is enough to repay the maturing debt $(\$ 75.95)$ and finance the full $\$ 25$ acquisition cost of the new project. In the bad state of the world, the firm would not be able to use assets in place to finance expansion. In fact, without access to other assets or capital infusions, it would be unable to raise enough cash to repay the maturing debt and would be forced to default at time 1 .

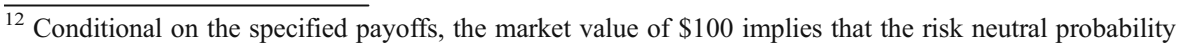
of the good state is .66.

${ }^{13}$ The face value (i.e., the required payoff at maturity) of the zero coupon debt is $\$ 75.95$ if the maturity is 1 year and $\$ 82.41$ for a two-year maturity.

${ }^{14}$ Default at time 1 is possible, but would depend on other factors such as the nature of bond covenants demanded by investors. If the debt is zero coupon and did not have covenants that triggered early redemption in the bad state, managers would have the right to continue to operate the firm until time 2.
} 


\section{Debt Maturity and the Flexibility to Use Assets in Place}

Panel A

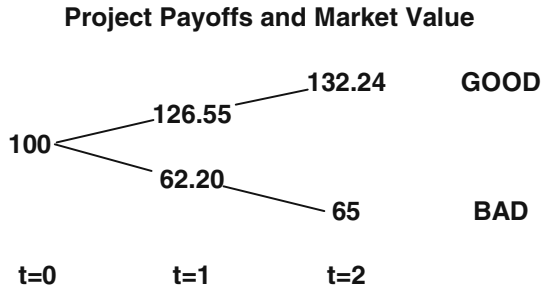

Panel B

Borrowing Capacity

Two Year Debt

\section{Call Price Value}

\section{Borrowing Capacity \\ One Year Debt}

\begin{tabular}{|c|c|c|c|c|c|}
\hline $\begin{array}{l}\text { Avail Collat. } \\
\text { Borr. Cap. }\end{array}$ & $\begin{array}{l}20.00 \\
14.00\end{array}$ & GOOD & $\begin{array}{l}\text { Avail Collat. } \\
\text { Borr. Cap. }\end{array}$ & $\begin{array}{l}146.55 \\
102.58\end{array}$ & GOOD \\
\hline $\begin{array}{l}\text { Avail Collat. } \\
\text { Borr. Cap. }\end{array}$ & $\begin{array}{l}20.00 \\
14.00\end{array}$ & BAD & $\begin{array}{l}\text { Avail Collat. } \\
\text { Borr. Cap. }\end{array}$ & $\begin{array}{l}82.20 \\
57.54\end{array}$ & BAD \\
\hline & $t=1$ & & & $t=1$ & \\
\hline
\end{tabular}

Fig. 1 Debt maturity and the flexibility to use assets in place

In addition to showing how short maturity debt provides managers an opportunity to use assets in place to finance empire building, the example also demonstrates how the nature of the investment decisions and risks can influence the shareholders' optimal choice of debt maturity (where optimal is defined as the choice that maximizes firm value). In the example, if we assume that there are many investment opportunities available and the main risk (from the owner's perspective) is overinvestment (i.e., making the negative NPV investment), long maturity debt achieves the first best decision - it assures that the poor investment is not made even in the good state. But, if the shareholders' main concern is to assure the timely liquidation of existing assets (as Benmelech 2006, assumes), then short maturity debt would assure the first best outcome in the bad state, whereas liquidation with longer maturity debt depended on the debtholders having the foresight to include the required covenants.

Hart and Moore (1995) and the example show that the optimal debt maturity choice, from a firm's perspective, is ambiguous: It depends on the firm's existing leverage and requires a balancing of costs and benefits. The primary benefit of longmaturity debt is that assets in place are encumbered thereby preventing management from using them to finance overinvestment or empire building. The cost, however, is the risk of creating a debt overhang which Myers (1977) shows can lead to underinvestment. Similarly, Hart and Moore (1995) show that the optimal maturity choice from the managers' perspective is also subject to conflicting factors. Whereas traditionally, it has been argued that managers will shun short-maturity debt to avoid 
the extra monitoring and liquidity risk associated with frequent capital market security issues, Hart and Moore (1995) show that short maturity debt provides managers an offsetting benefit - the flexibility to use assets in place to pursue empire building.

Although, the optimal choice of maturity may be ambiguous in general, because REITs must raise capital on a regular basis as a result of the high dividend payout requirement, the incremental monitoring cost for management is small and we believe self-serving managers will find the benefit of the flexibility achieved with short-term debt outweighs the marginal monitoring costs leading entrenched REIT managers to favor short-maturity debt. Similarly, the same institutional features of REITs combined with the tendency of managers to empire build should tip the balance for shareholders (and managers aligned with their interests) toward a preference for long-term debt.

Marchica (2005) analyzes the relationship between debt maturity and managerial ownership. More specifically, she investigates the possibility of a non-linear relationship between debt maturity and ownership. Her theoretical development recognizes the possibility of a divergence of interests between shareholders and managers. She hypothesizes that small ownership stakes might actually increase managerial risk aversion with respect to liquidation risk-leading to greater use of long maturity debt. She argues that only when managers have large stakes will the alignment effect outweigh the liquidity risk and induce managers to shorten maturity. ${ }^{15}$ Using a sample of firms from the U.K., she finds evidence of the predicted non-linear, U-shaped, relationship between the size of management ownership and maturity. Recognizing that leverage may interact with the maturity decision, she separated her sample into high leverage and low leverage firms and finds the non-linear relationship to be especially significant for high leverage firms. Marchica (2005) further argues that short-term debt and managerial ownership interest are alternative managerial control mechanisms.

Two recent papers have used an instrumental variables approach to modeling debt maturity: Jiraporn and Kitsabunnarat (2008) and Datta et al. (2005). Jiraporn and Kitsabunnarat (2008) estimate both a single equation for maturity (which excludes leverage) and a 2SLS version which includes the predicted leverage from the first stage. Their primary interest is the effect of the Governance Index (obtained from IRRC) on the firm's debt maturity choice and they find a positive and significant relationship between that index and the percentage of debt maturing beyond 2 years and 5 years in both specifications. They argue that because a high value for the Governance Index is associated with weak governance, the positive relationship is consistent with the assumption that managers, acting without significant restraint by shareholders, will choose long-maturity debt to minimize the liquidation risk and the increased monitoring associated with short term debt. ${ }^{16}$ Their estimated 2SLS model does not allow for maturity to influence the choice of leverage because the first stage

\footnotetext{
${ }^{15}$ Marchica (2005) makes an underlying assumption that because short-maturity debt is more effective at reducing the Myers (1977) underinvestment problem, it would be preferred by shareholders. Hart and Moore (1995) and the preceding argument show that shareholders will not always prefer short-maturity debt because long-maturity debt is more effective for reducing over-investment.

${ }^{16}$ As noted earlier, if the primary concern of shareholders is limiting over-investment, long-maturity debt could be the optimal choice of the shareholders as well as the managers.
} 
regression for leverage does not include debt maturity and is identified primarily by measures of tax incentives for debt. Datta et al. (2005) also used a simultaneous equation approach to study the effect of managerial ownership on debt maturity. Their paper focuses exclusively on the effect of managerial stock ownership and does not include other measures of existing governance measures. ${ }^{17}$ They report a negative relationship between managerial alignment (as measured by managerial stock ownership) and maturity. While this result is generally consistent with the findings of Benmelech (2006) and Jiraporn and Kitsabunnarat (2008), it does not take into consideration the effect of other governance mechanisms or the possibility of substitution of one mechanism for another. Curiously, the Datta et al. (2005) and Jiraporn and Kitsabunnarat (2008) papers find firm growth opportunities (as proxied by the ratio of market capitalization to book equity) to be positively related to debt maturity, a finding that is opposite the conventional wisdom and the findings of most previous empirical studies (e.g., Benmelech 2006, Johnson 2003 and Barclay et al. 2003) that firms with significant growth opportunities use more short-maturity debt. $^{18}$

A recent working paper, Harford et al. (2007) investigates whether strong boards are better able to impose a capital structure on managers. However, although they instrument for leverage and use the predicted leverage in a debt maturity equation, like Jiraporn and Kitsabunnarat (2008) they do not estimate a complete simultaneous equation system that allows maturity to affect the leverage choice and as well as the reverse. They find that firms with stronger boards use more short-term debt, but they find no support for their other hypothesis that firms with stronger boards use more leverage.

\section{Model Specification and Data}

\section{Choice of Variables}

Because it is well established in theory and recent empirical research that firms simultaneously choose leverage and maturity, we estimate a two-equation system of simultaneous equations - one for leverage and one for maturity. The specification for each equation includes three categories of explanatory variables: 1) firm financial variables, 2) measures of asset liquidation value and 3) measures of managerial entrenchment, alignment and the existing governance structure. While the focus of this paper is on the effect of the variables in the third category, it is nevertheless important that the models adequately control for the influence of factors that previous research has shown to influence capital structure in order to avoid omitted variable bias and spurious correlations. Our selection of variables in all three categories is guided by previous research. The discussion in this section is not

\footnotetext{
${ }^{17}$ Datta et al. (2005) do not report their leverage equation. We were unsuccessful in obtaining those results from the authors.

18 The rationale for short-maturity debt is that for firms with significant growth opportunities in the future, shareholders will place greater emphasis on avoiding debt overhang and the risk of underinvestment.
} 
intended to be comprehensive and readers are directed to the original references for more detail. The discussion is organized around the three major categories.

Firm Financial Variables The selection of control variables for the standard financial factors is guided primarily by the work of Stohs and Mauer (1996) and Johnson (2003). The selected variables and their hypothesized effects are summarized in Table 1.

The first financial variable is the ratio of market value to book value. This variable is customarily used as a measure of a firm's growth opportunities. The hypothesized effect of growth opportunities on both leverage and debt maturity is negative. The use of debt introduces the potential for conflict between debtholders and shareholders. Myers (1977) showed that one result of this conflict was a tendency for firms with a significant long-term debt overhang to forego positive net present value investments when a portion of the investment payoff benefits the existing debtholders and not the shareholders (the "underinvestment problem"). Both Myers (1977) and Hart and Moore (1995) show that firms with lower leverage and shorter maturity debt have more ability to finance new positive NPV projects and thus firms with growth opportunities should use lower leverage and shorter maturity debt, ceteris paribus. Avoiding the underinvestment problem is most important for firms with significant growth opportunities.

Table 1 Traditional firm characteristics influencing capital structure

\begin{tabular}{|c|c|c|}
\hline & Leverage & Maturity \\
\hline Traditional Corporate Finance Factors & & \\
\hline Growth Opportunities & - & - \\
\hline Market-to-Book Ratio & & + \\
\hline Firm Quality & - & - \\
\hline Firm Size & & + \\
\hline Firm Size Squared & - & + \\
\hline Volatility of Cash Flow & - & - \\
\hline Firm Age & & \\
\hline Asymmetric Information/Signaling & & \\
\hline Earnings Growth & & \\
\hline Pecking Order Theory & & \\
\hline Profitability (Return on Assets) & - & \\
\hline Maturity Matching & & + \\
\hline Asset Maturity & & \\
\hline Market Access & & + \\
\hline Market Access & + & + \\
\hline
\end{tabular}

This table summarizes the firm characteristics traditionally used in empirical studies of leverage and/or debt maturity. The signs in the two rightmost columns indicate the predicted direction of the effect. A shaded cell in a column indicates that the variable is excluded from that model and shows the restrictions on the coefficients used to identify the system of equations

The gray shaded cells denote the exclusionary restrictions used to identify the system of equations. These restrictions are the same as those used in previous capital structure literature, including Johnson (2003)

The financial variables listed above should be interpreted as representing generic firm characteristics. Various proxies may be used in different papers to represent these characteristics. The specific proxies used in this paper are defined in the Data Section 
The introduction of debt into a firm's capital structure creates a bankruptcy risk that does not exist for an all-equity financed firm. This means that shareholders must trade-off the tax and monitoring benefits of debt against the liquidity risk associated with the use of debt. Liquidity risk increases with both leverage and the use of short-maturity debt. According to Myers (1993), one of the "most striking facts about corporate finance" is the negative correlation between firm profitability and leverage. Firms with strong earnings and low credit risk (high-quality firms) use lower leverage. While there might be some question of cause and effect in this stylized fact, this stylized fact is consistent with Myers (1984) pecking order theory since current earnings tend to be the lowest cost source of investment funds. ${ }^{19}$ With respect to the relationship between firm quality and maturity structure, Diamond (1991) argues that high credit quality firms choose to use short maturity debt to signal their confidence that they will be able to rollover maturing debt in both good and bad markets while riskier firms choose longer maturity debt to minimize the liquidity risk of leverage. Because very risky firms (low quality firms) are forced by lenders to use short maturity debt, the resulting relationship between firm quality and the use of short-term debt is generally viewed as being U-shaped.

Following Johnson (2003) and Stohs and Mauer (1996), we use firm size and the volatility of earnings as proxies for firm quality. ${ }^{20}$ In addition, we include firm age in this category, measured as the time since the firm's Initial Public Offering (IPO) of common stock, to control for any systematic changes in financing needs with experience and firm maturity (Faulkender and Peterson 2006). We measure firm size as the natural $\log$ of the market value of firm assets (measured in billions of 2006 dollars) and volatility of earnings as the time-series standard deviation of funds from operations. ${ }^{21}$ We also include firm size squared in the maturity equation to control for the possible non-linearity predicted by Diamond (1991). Table 1 shows that we expect both firm size and volatility of earnings to be negatively related to leverage and positively related to debt maturity. If there is enough variability in firm quality in the sample, we would expect a negative sign on firm size squared to the extent that very high quality firms use short maturity debt to signal their high quality. Finally, we predict a negative relationship between firm age and leverage and a positive relationship between firm age and debt maturity. This prediction is based on the observation that mature firms should have lower financing needs and well-

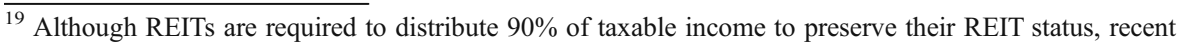
research (need citations) has shown that REITs nevertheless have significant internally generated cash flow, largely due to significant depreciation expenses.

${ }^{20}$ As reported by Barclay et al. (2003), large firms tend to have more collateralizeable assets and more stable cash flows and are less likely to default. Firms with greater volatility of earnings and cash flows face greater risk of inability to refinance in bad times (see Johnson 2003).

${ }^{21}$ The term "Funds from Operations" (FFO) is defined as net operating income from the properties owned by the REIT. Net operating income is essentially the difference between rental income and building operating expenses. FFO measures net cash flow from the properties and does not include interest expense, depreciation or corporate taxes. Because REITs generally include large non-cash depreciation expenses, volatility of FFO is generally deemed to be a better measure for REITs of the riskiness of cash flow available to support debt than volatility of net income or stock price volatility.
} 
established sources of long-term financing than do younger firms. See Faulkender and Peterson (2006) for empirical evidence supporting these predictions.

The next financial control variable in Table 1, Earnings Growth, proxies for the possible influence of asymmetric information on the firm's choice of capital structure. Flannery (1986) and Diamond (1991, 1993) argue that firms with favorable inside information about future firm prospects should use short-maturity debt that can be refinanced at lower cost when the favorable information becomes public. Both Stohs and Mauer (1996) and Johnson (2003) find evidence supporting this prediction. Following these authors, we use the forward-looking actual growth rate of earnings $\left.\left(\left(\mathrm{EPS}_{\mathrm{t}+1}-\mathrm{EPS}_{\mathrm{t}}\right) / \text { Share Price }\right)_{\mathrm{t}}\right)$ to proxy for the asymmetric information effect in the maturity equation and expect a negative sign.

The remaining financial controls include a measure of profitability, asset maturity and a dummy variable that takes on a value of one if the firm has a debt rating issued by at least one of the three major rating agencies. Myers (1984) pecking order theory predicts that because retained earnings have the lowest all-in cost, profitable firms will prefer to finance investments from retained earnings and will use less leverage. We measure profitability using the return on assets. Graham and Harvey (2001) find that corporate financial officers report that the desire to match the maturity of assets and liabilities is a major determinant of debt maturity. Johnson (2003), Stohs and Mauer (1996) and Datta et al. (2005) all find empirical support for this maturity matching effect. As in these previous empirical studies, we measure asset maturity (in years) as the ratio of the dollar value of real estate assets to the reported depreciation expense. ${ }^{22}$ Asset maturity is used solely in the maturity equation and is expected to be positively correlated with debt maturity. Finally, firms with debt rated by one of the three major rating agencies should have more flexibility in selecting their capital structure. Faulkender and Peterson (2006) find that a firm's access to the public debt market has a large effect on its leverage ratio. Furthermore, we expect that firms with public debt ratings should have greater access to the capital markets to raise longer maturity corporate debt than do unrated firms that depend more on shorter-maturity bank credit. However, given the tangible nature of most REIT assets and the ability of all REITs to tap the mortgage market for long-term collateralized debt, this effect may be less noticeable for our sample than for industrial firms.

Asset Liquidation Value Shleifer and Vishny (1992) argue that, in equilibrium, firms with assets that are more easily redeployed in the event of financial distress (i.e., assets with high liquidation values) will use higher leverage and longer maturity debt than firms with less liquid assets. Benmelech (2005), Benmelech et al. (2005) and Giambona et al. (2008) provide empirical support for this theoretical prediction. In particular, Giambona et al. (2008) show that asset liquidation value significantly influences a firm's capital structure choices. Firms with assets that are easily redeployed in the event of financial distress use higher leverage and longer maturity debt. Following Giambona et al. (2008), we use two different measures of asset

\footnotetext{
${ }^{22}$ The tax code specifies minimum assumed useful lives for commercial real estate assets. As a result, this measure is likely to contain less firm specific information for REITs than for the industrial firms studied by previous researchers.
} 
liquidation value: The average maturity of outstanding leases on the properties in the REIT's portfolio and the average recovery value for the REIT's assets. ${ }^{23}$ The rationale for using lease maturity is that longer-term leases reduce the property owner's flexibility to redeploy the physical assets to a better use in the event of financial distress. The recovery value is a direct measure of liquidation value because it is a weighted average of the foreclosure recovery rates from foreclosed properties backing Commercial Mortgage-Backed Securities (CMBS). For each REIT, the percentage of the portfolio invested in each property type is multiplied by the estimated recovery rate for the property type to generate the recovery value measure. Consistent with Shleifer and Vishny (1992) and Giambona et al. (2008) we expect that firms with more liquid assets will have higher leverage and longer maturity debt.

Governance The focus of this paper is on estimating how governance variables influence the firm's observed capital structure choices. We group the governance measures into three categories: 1) variables that measure managerial entrenchment including CEO tenure and various indicators of the degree of insulation from market forces such as the use of poison pill provisions; 2) variables that measure the extent of alignment of CEO objectives with those of the shareholders (e.g., ownership); and 3) variables that proxy for board effectiveness or the ability of the board to impose its will on management.

Our choice of governance variables is based on previous studies of the influence of governance variables on firm capital structure, primarily Berger et al. (1997). Our choices also reflect previous research on the influence of governance variables on other corporate decisions, performance and the market reaction to events. For example, Hartzell et al. (2006) study the relationship between governance mechanisms and REIT investment decisions, Hartzell et al. (2008) study the role of governance on the market reaction to an IPO, and Feng et al. (2005) examine the relationship between board structure and REIT performance. These and other studies helped guide our choice of governance variables.

Much of the early capital structure literature assumed alignment of the interests of managers and shareholders and, at most, analyzed how the agency problems associated with the inherent conflict between debtholders and shareholders influenced capital structure (e.g., the underinvestment problem raised by Myers 1977). With the assumption of perfect alignment, there is little role for most governance variables. Furthermore, in the absence of shareholder/manager agency problems, short-term debt appears to be attractive to both shareholders and debtholders since it can reduce both the underinvestment problem and risk-shifting behavior. ${ }^{24}$ The risk of overinvestment

\footnotetext{
${ }^{23}$ Giambona et al. use a set of property focus indicator variables as a third measure of liquidation value. These three alternative measures of liquidation value are highly correlated and in some cases perfectly collinear. For example, given the one-day lease maturity assigned to all hotels, it is impossible to include the property type indicators with the lease maturity proxy. Although the recovery index exhibits some variation for REITs with the same property focus (because a REIT defined as a "hotel" REIT may hold some non-hotel assets) the correlation is high enough to preclude including property type indicators in the recovery index specification. We further found that there was little new information related to the effects of governance variables provided by estimating a third model with just property type indicators and consequently only use lease maturity and the recovery index as measures of liquidation value.

${ }^{24}$ The term risk-shifting refers to the incentive that shareholders have to undertake higher risk projects once long-term debt has been sold. That incentive arises because the shareholders essentially own a call option on the firm's assets and increased volatility of the firm's assets increases the value of the call option and reduces the value of the debt. See Eisdorfer (2008) for further discussion and evidence.
} 
is eliminated by the frequently-made perfect alignment assumption. However, once the assumption of perfect alignment is dropped, governance variables emerge as important control mechanisms that are more directly under shareholder control than is capital structure. Given the possible divergence between the interests of managers and shareholders, it is important to include governance variables that measure all three categories: entrenchment, alignment and board effectiveness.

The variables used by Berger et al. (1997) include a single measure of managerial entrenchment (CEO tenure), two measures of the financial alignment of management (CEO stock ownership and CEO option holdings) and several descriptors of existing shareholder monitoring mechanisms including board size and the composition of the board (e.g., percent independent). ${ }^{25}$ In addition to these variables, we include several other measures that have been used in studies of the influence of governance variables on other corporate finance issues. Specifically, we expand the measures of CEO entrenchment by including an indicator for CEOs that also hold the position of Chairman of the Board (CEO/COB duality) as well as indicators for various forms of anti-takeover protection. These provisions include whether the firm has a poison pill or excess share plan ${ }^{26}$ in place and an indicator for incorporation in the state of Maryland. ${ }^{27}$

Following Berger et al. (1997), we include measures of CEO stock and option ownership as proxies for CEO alignment. We allow for a non-linear ownership effect using two indicators: a low ownership indicator that takes on a value of one if the CEO owns less than $1 \%$ of the outstanding shares and a second indicator that is set to one if the CEO owns more than $5 \%$ of the stock. These ownership cutoff values are approximately the 25th and 50th percentiles of the CEO ownership distribution. ${ }^{28} \mathrm{We}$ expand the Berger et al. (1997) measures of alignment by including an indicator that flags observations where the CEO is the founder of the firm. Many REITs trace their origin to large family-controlled real estate portfolios and the chief executive of these family-run operations frequently took over as CEO after the IPO. We believe that the objectives of these CEO/Founders are likely to be strongly aligned with those of the shareholders - in part because other family members are likely to be significant

\footnotetext{
${ }^{25}$ Berger et al. (1997) also include an indicator for the presence of a large blockholder. We considered using a similar variable, but found that approximately $90 \%$ of the REITs in our sample have at least one large blockholder. This lack of heterogeneity suggests that further exploration of the blockholder effect for REITs would require detailed information describing the size of the holding and the identity of the blockholder (e.g., insider, institutional, etc.). Our data does not include this detailed information and we were not able to include blockholder information in our model specifications.

${ }^{26}$ An excess share plan facilitates a REIT's compliance with the special REIT ownership distribution rulescommonly referred to as the five or fewer rule. This rule prohibits any five (or fewer) individuals from controlling more than $50 \%$ of the outstanding shares. An excess share plan restricts the percentage ownership of any individual to generally $10 \%$ or less. The restriction is enforced by stripping any shares in excess of the limit of voting and dividend rights.

${ }^{27}$ Hartzell et al. (2006) and Hartzell et al. (2005) both use incorporation in the state of Maryland as a proxy for entrenchment because trust law in Maryland is management-friendly and helps insulate firms from the market for capital control.

${ }^{28}$ Previous research, such as Marchica (2005), suggests that a much higher cutoff (e.g., 25\%) may be required to identify the predicted non-linear relationship between ownership and debt maturity. Given our small sample size, we were unable to explore the effects of very high ownership.
} 
shareholders and also because both the founder's wealth and personal reputation is linked to the performance of the firm. ${ }^{29}$

Finally, Berger et al. (1997) included board size and the percentage of the board that was independent as proxies for board effectiveness. Conventional wisdom holds that large boards are less effective while those with more independent members will be more effective. Lipton and Lorsch (1992) and Jensen (1993) argue that boards become less effective as they increase in size because coordination problems become more significant with size. They also argue that the free rider problem becomes more severe as the board size increases. Eisenberg et al. (1998) and Mak and Kusnadi (2004) provide empirical support showing a negative relationship between board size and market value. If small boards are indeed more effective at monitoring and directing managers, then we would expect a negative relationship between board size and both leverage and debt maturity. Similarly if boards with a large percentage of independent members are more effective at monitoring and directing management's choices, then we should see a positive relationship between the percentage of the board that is independent and both leverage and maturity. In addition to these measures of board effectiveness, we include an indicator for staggered board terms. While a staggered board has often been viewed as an anti-takeover measure (Masulis et al. 2007) that could insulate management from the market for corporate control and the threat of takeover, recent research suggests that this view may be oversimplified. A contrasting view has been espoused by Wilcox (2002), Rose (2009), and Campbell et al. (2009). These authors argue that the longer board terms associated with staggered boards strengthen board members in their dealings with the CEO since they do not need to stand for re-election each year. For REITs, which are already well-insulated from takeover threats, we believe this latter effect is likely to dominate. ${ }^{30}$

Table 2 shows the predicted signs for each of the governance variables in the leverage and debt maturity equations. The first group of variables (CEO tenure, $\mathrm{CEO} / \mathrm{COB}$ duality and the indicators for various forms of anti-takeover

\footnotetext{
${ }^{29}$ A largely positive view of founder control in large US corporations emerges from the analysis by Adams et al. (2009). On average, founders increase the performance of their firms and they only step out if their firms are doing well. The message that founder control is beneficial is consistent with most of the recent literature. Fahlenbrach (2009) reports that founder-CEO firms invest more in research and development, have higher capital expenditures, and make more focused mergers and acquisitions.

${ }^{30}$ Masulis et al. (2007) find that an indicator for staggered board has a significantly negative effect on abnormal returns of bidding firms around acquisition announcements. The authors interpret this evidence as consistent with the hypothesis that managers at firms protected by anti-takeover provisions are less subject to the disciplinary forces of the market for corporate control. Conversely, Wilcox (2002) contends that a staggered board protects a director who refuses to succumb to pressure to comply with the agenda preferred by management. A classified board also allows more time to review a takeover bid and solicit competing offers. These potential benefits aside, Rose (2009) asserts that the negative relation between staggered board and firm value must be interpreted from the perspective of a firm's vulnerability to hostile takeovers. Rose contends that staggered boards are more harmful for firms that are takeover targets. For firms with low takeover probability, a staggered board should have no significant impact on firm value. Campbell et al. (2009) report that the presence of staggered board has no significant impact on the announcement period abnormal returns of acquiring REITs. Recalling that discipline by the market for corporate control is virtually absent among REITs, the authors interpret this result as consistent with Rose's view that a staggered board is detrimental to shareholder wealth only for firms that are under a serious hostile takeover threat.
} 
Table 2 Governance variables influencing capital structure

\begin{tabular}{llc}
\hline Governance Variables & Leverage & Maturity \\
\hline Entrenchment & & - \\
LN(CEO Tenure) & - & - \\
CEO/COB Duality & - & - \\
Maryland Charter & - & - \\
Poison Pill Plan in Place & - & - \\
Excess Share Plan in Place & - & + \\
Alignment & & + \\
CEO Ownership of Common Stock & + & + \\
CEO Vested Options & + & - \\
CEO Founder of Firm & + & + \\
Internal Corporate Governance & & + \\
Board Size & - & + \\
Percent of Board Independent & + & + \\
Staggered Board Terms & + & \\
\hline
\end{tabular}

This table summarizes the hypothesized effects of the variables that measure management entrenchment, alignment and internal control mechanisms. The signs in the two rightmost columns indicate the predicted direction of the effect

The system of simultaneous equations is identified using exclusionary restrictions on certain firm characteristics. All of the above variables are included in the model specification

The specific definitions of the variables are included in the Data Section

protection) measures the balance of power between management and shareholders. We expect CEOs with long tenure, with the added power of being Chairman and those that are well-insulated from the market for control to be more entrenched and thus more likely to be able to select a capital structure that favors their personal objectives over those of the shareholders. The prediction in Table 2 that increased power for management (i.e., long tenure and/or insulation from market forces) will result in a capital structure with lower leverage is based on the observation that high leverage increases the career risk of managers, reduces free cash flow for perquisites and empire building and subjects them to increased capital market monitoring, while almost all of the benefits of higher leverage accrue to the shareholders. The predictions with respect to maturity reflect the assumption that because REIT managers already face regular capital market scrutiny and monitoring resulting from the dividend payout requirement, REIT managers will find that the benefits of the flexibility achieved with short maturity debt outweigh the marginally higher monitoring burden and liquidity risk.

The next group of governance variables (CEO ownership of common stock, vested option holdings and an indicator for firms where the CEO is the founder of the firm) measures the alignment of interests between the CEO and owners. Consistent with the preceding discussion, we expect the first order linear effect of alignment on leverage to be positive but the effect on debt maturity to be 
determined by whether overinvestment or underinvestment is the most significant concern of owners. ${ }^{31}$ However, as with the entrenchment variables, the unique characteristics of REITs help resolve this uncertainty. Because REITs are already forced to bear the liquidity risk associated with regularly raising capital from the market, we believe that shareholders' interests are best served by longer maturity debt. Therefore, we predict that managers whose interests are aligned with those of the other owners will choose longer maturity debt.

The final group of variables includes the three measures of board effectiveness. The first two are board size and the percentage of independent board members and the third is an indicator for staggered board terms. As discussed above, we expect large boards and boards with fewer independent members to be less effective at limiting management's efforts to keep leverage low and maturity short. We also predict that staggered board terms contribute positively to board effectiveness and therefore should have a positive relationship with both leverage and debt maturity.

\section{Model Specification}

The simultaneous equation system has the general form:

$$
\begin{gathered}
\text { Leverage }=\beta_{0}+\bar{\beta}_{1} \overline{\mathrm{F}}+\bar{\beta}_{2} \overline{\mathrm{L}}+\bar{\beta}_{3} \bar{G}+\varepsilon_{L} \\
\operatorname{Ln}(\text { DebtMaturity })=\gamma_{0}+\bar{\gamma}_{1} \bar{F}+\bar{\gamma}_{2} \overline{\mathrm{L}}+\bar{\gamma}_{3} \bar{G}+\varepsilon_{D M}
\end{gathered}
$$

where $\bar{F}, \bar{L}$, and $G$ represent vectors of firm financial variables, liquidation value proxies and governance variables, respectively. In the above equations, leverage is defined as the ratio of total book value of debt to the market value of the firm's assets. We differ from many previous studies by using the actual debt maturity measured in months and not simply the percent of debt maturing beyond a specified future date. ${ }^{32}$ The maturity used in our estimation makes full use of the firm's reported maturity structure. Because the debt maturity exhibits right skewness, we use the natural logarithm of debt maturity. ${ }^{33}$

\footnotetext{
${ }^{31}$ Marchica (2005) argues and provides supporting evidence that the effect of CEO ownership may be nonlinear. We did not include quadratic terms related to ownership because of excessive colinearity.

32 The SNL reports provide the dollar amount of debt maturing in each of the next 5 years and the total of debt maturing in 6 years or longer. We calculate a weighted average maturity using the percentage of the debt maturing in each category and the midpoint of the category as the maturity for all debt in that category. For example, if a firm with $\$ 40$ million of total debt had $\$ 10$ million of debt maturing in the next 12 months and $\$ 30$ million of debt maturing in months $37-48$, we would calculate the average maturity as $(10 * 6.5+30 * 42.5) / 40=33.5$ months. We estimate the maturity of the debt maturing after 5 years by calculating the average annual dollar amount of debt maturing in the first 5 years and assuming that the same rate of roll-off continues in the future until all debt matures.

${ }^{33}$ Much of the maturity literature uses the percentage of debt maturing after a specified future date (e.g., 3 years or 5 years from the date of the financial statement). The estimated maturity used in this paper makes better use of the available maturity information and we believe is preferable to the easier to collect but less precise percentages frequently used. In the Robustness Section we discuss results of estimating the model using these alternative definitions.
} 
Following Johnson (2003) and Giambona et al. (2008) we identify the system of equations by excluding certain financial variables from each of the equations. As Table 1 shows, we excluded firm size squared, earnings growth and asset maturity from the leverage equation because theory suggests that these variables only influence maturity. We exclude the measure of profitability, return on assets, from the maturity equation because, after controlling for earnings growth, current profitability should only influence the choice of leverage. We estimate the model using two-stage least squares (2SLS).

\section{Data}

Our initial sample includes 136 equity REITs from the SNL Datasource database that specialize in one of the five major property types. ${ }^{34}$ The balance sheet and income statement items required for the estimation were obtained from COMPUSTAT and other variables from SNL Datasource. Although data was collected for the period from 1997 through 2007, the resulting panel available for estimating the models terminates in 2006. We chose 1997 as the starting year for data collection because data for some key variables used in the analysis are not available in COMPUSTAT or SNL Datasource prior to 1997. The panel available to estimate the models terminates in 2006 because the forward-looking earnings growth control variable is only defined through $2006 .{ }^{35}$ We hand collected the governance variables from proxy statements and $10-\mathrm{K}$ forms for each firm year in the sample. We collected data describing the average lease maturity for retail, office and industrial REITs from their 10-K statements and assigned a six-month lease maturity to all apartment REITs and a one-day lease maturity to hotel REITs. ${ }^{36} \mathrm{We}$ obtained the recovery values for each property type from the 2005 Standard and Poor's analysis of defaults on CMBS (Standard and Poor's 2005). We calculated the recovery index for each REIT year as the inner product of a vector of property type allocation percentages and the vector of property type recovery values. ${ }^{37}$ After eliminating observations that were missing data for any of the independent variables, the final sample comprises fifty-one equity REITs for which we have

\footnotetext{
$\overline{34}$ This excludes REITs that specialize in health care, manufactured housing, self-storage facilities and diversified REITs.

35 The forward-looking growth rate of earnings requires information on earnings per share in 2007 to create the 2006 variable.

${ }^{36}$ Most apartment and hotel REITs do not provide detailed lease maturity data. We applied the same methodology used to calculate average debt maturity to calculate the average maturity of leases given a schedule of lease maturities over the next 5 years and beyond.

${ }^{37}$ More specifically, we use the reported recovery rates for the five major commercial property types: apartment, retail, office, industrial and hotel. The index is calculated using the equation:

Recovery Index $=($ CMBS recovery $\%$ for apartmentloans $\%$ of REIT portfolioin apartments $)$ $+($ CMBS recovery $\%$ for retailloans $\%$ of REIT portfolioin retail properties $) ..$
}

To calculate a recovery index for a REIT, we require that the sum of the percentages invested in the five major property types exceed $95 \%$ and normalize by that sum. 
one or more complete observations over the sample period and 318 pooled time series, cross-sectional observations. ${ }^{38}$

Table 3 provides summary statistics for the variables used in the estimation. Retail REITs represent the largest portion of the sample (40\%), closely followed by office REITs (32\%). In combination, these two REIT types represent $27 \%$ of the sample. Apartment REITs and industrial REITs account for approximately seventeen and 7\% of the sample, respectively. Hotel REITs represent less than $5 \%$ of the sample. The average market value of the assets of these firms was approximately $\$ 5$ billion dollars, measured in 2006 constant dollars.

The REITs in this sample use more leverage and longer maturity debt than do the primarily industrial firms studied by Johnson (2003), Stohs and Mauer (1996) or Datta et al. (2005). ${ }^{39}$ All REIT types have average market-to-book ratios in excess of one and all but hotel REITs had positive average return on assets over the sample period. Roughly $55 \%$ of the sample has public credit ratings. For the whole sample, annual earnings growth averaged near zero, but varied significantly by REIT type with hotels, which were just emerging from a deep recession near the end of the sample period reporting the only significant positive growth. Consistent with the deep recession in travel post 9/11, hotel REITs also experienced very high volatility of cash flow.

The average lease maturity for the entire sample is somewhat greater than 4 years, but varies significantly by property type. Because retail and office REITs represent more than $70 \%$ of the sample, the overall average is strongly influenced by the longer leases typical in those businesses (6.2 years and 4.8 years, respectively). Foreclosed apartment loans experienced the highest recovery rates in the S\&P study and so apartment REITs had the highest recovery index value (70\%). Commercial loans on hotels experienced the greatest losses in the S\&P study and so hotel REITs have a recovery index of approximately $50 \%$.

Turning to the governance variables, the table shows that the average CEO tenure was just less than 8 years, similar to the tenure reported by Berger et al. (1997) for their sample of industrial firms. Typical CEO tenure ranged from a low of about 7 years for apartment REITs to 8.5 years for retail REITs. Because CEO tenure exhibits right skewness, we use the natural logarithm of tenure in the estimation. Approximately $46 \%$ of the CEO's in the sample also held the position of Chairman of the Board and $60 \%$ of the REITs were chartered in Maryland, a state considered to have trust law very favorable to management. Roughly one-third of the sample firms

\footnotetext{
${ }^{38}$ Of the initial population of 136 REITs, twenty-six were lost because the SNL Datasource did not have the required financial variables (i.e., those listed in Table 1). Forty additional REITs were lost because they did not provide a schedule of debt maturities in the notes to their financial statements. The remaining nineteen were dropped because of missing lease data or governance data. Despite the significant reduction in the number of REITs from 2003, we believe the surviving sample is representative of the current REIT population. For example, as of August 31, 2009, after excluding specialty REIT categories, NAREIT includes seventy equity REITs in its REIT index. Both the number of REITs and the distribution of property-focus in our sample are similar to that reported by NAREIT once the population is limited to those REITs specializing in one of the five major property types.

${ }^{39}$ For example, the average leverage for REITs in our sample is 43\%. Johnson (2003), Stohs and Mauer (1996) and Datta et al. (2005) report 21\%, 20\% and 16\%, respectively, for their samples of non-REIT firms. The average debt maturity in our sample is 5.6 years while the average maturity reported by Stohs and Mauer (1996) was 3.4 years.
} 
Table 3 Descriptive statistics

\begin{tabular}{|c|c|c|c|c|c|c|}
\hline Variable & All REITs & Industrial & Residential & Hotel & Retail & Office \\
\hline \multicolumn{7}{|c|}{ Endogenous Dependent Variables } \\
\hline Leverage & $\begin{array}{c}0.43 \\
(.11)\end{array}$ & $\begin{array}{c}0.37 \\
(.05)\end{array}$ & $\begin{array}{l}0.47 \\
(.12)\end{array}$ & $\begin{array}{c}0.50 \\
(.1)\end{array}$ & $\begin{array}{c}0.44 \\
(.11)\end{array}$ & $\begin{array}{c}0.41 \\
(.09)\end{array}$ \\
\hline Debt Maturity (Mo.) & $\begin{array}{l}66.81 \\
(31 .)\end{array}$ & $\begin{array}{r}75.00 \\
(46.7)\end{array}$ & $\begin{array}{c}74.05 \\
(34.93)\end{array}$ & $\begin{array}{c}69.53 \\
(28.19)\end{array}$ & $\begin{array}{c}66.30 \\
(30.91)\end{array}$ & $\begin{array}{c}61.35 \\
(23.59)\end{array}$ \\
\hline \multicolumn{7}{|c|}{ Firm \& Financial Variables } \\
\hline Market-to-Book & $\begin{array}{l}1.30 \\
(.26)\end{array}$ & $\begin{array}{l}1.41 \\
(.21)\end{array}$ & $\begin{array}{l}1.29 \\
(.24)\end{array}$ & $\begin{array}{l}1.08 \\
(.17)\end{array}$ & $\begin{array}{l}1.39 \\
(.28)\end{array}$ & $\begin{array}{l}1.19 \\
(.21)\end{array}$ \\
\hline Firm Size $(\$ B)$ & $\begin{array}{c}4.90 \\
(6.78)\end{array}$ & $\begin{array}{c}6.23 \\
(6.1)\end{array}$ & $\begin{array}{c}3.19 \\
(2.76)\end{array}$ & $\begin{array}{c}1.48 \\
(1.39)\end{array}$ & $\begin{array}{c}5.47 \\
(8.05)\end{array}$ & $\begin{array}{c}5.32 \\
(6.95)\end{array}$ \\
\hline Return on Assets (\%) & $\begin{array}{c}3.23 \\
(2.75)\end{array}$ & $\begin{array}{c}4.26 \\
(1.08)\end{array}$ & $\begin{array}{c}3.60 \\
(3.83)\end{array}$ & $\begin{array}{r}-1.15 \\
(3.2)\end{array}$ & $\begin{array}{c}3.31 \\
(2.33)\end{array}$ & $\begin{array}{c}3.30 \\
(2.17)\end{array}$ \\
\hline Volatility & $\begin{array}{c}0.60 \\
(1.98)\end{array}$ & $\begin{array}{c}0.44 \\
(.14)\end{array}$ & $\begin{array}{c}0.33 \\
(.19)\end{array}$ & $\begin{array}{c}1.22 \\
(1.13)\end{array}$ & $\begin{array}{c}0.85 \\
(3.09)\end{array}$ & $\begin{array}{c}0.37 \\
(.28)\end{array}$ \\
\hline Earnings Growth & $\begin{array}{r}0.02 \\
(4.9)\end{array}$ & $\begin{array}{c}0.00 \\
(2.15)\end{array}$ & $\begin{array}{c}-0.87 \\
(5.03)\end{array}$ & $\begin{array}{c}4.58 \\
(12.34)\end{array}$ & $\begin{array}{l}0.21 \\
(.21)\end{array}$ & $\begin{array}{r}-0.35 \\
(4.28)\end{array}$ \\
\hline Market Access & $\begin{array}{c}0.55 \\
(.5)\end{array}$ & $\begin{array}{l}1.00 \\
(.)\end{array}$ & $\begin{array}{c}0.55 \\
(.5)\end{array}$ & $\begin{array}{c}0.43 \\
(.51)\end{array}$ & $\begin{array}{c}0.56 \\
(.5)\end{array}$ & $\begin{array}{c}0.46 \\
(.5)\end{array}$ \\
\hline Asset Maturity (Yr.) & $\begin{array}{c}33.83 \\
(9.51)\end{array}$ & $\begin{array}{c}30.72 \\
(5.97)\end{array}$ & $\begin{array}{c}32.92 \\
(6.43)\end{array}$ & $\begin{array}{c}30.81 \\
(5.2)\end{array}$ & $\begin{array}{c}35.96 \\
(11.58)\end{array}$ & $\begin{array}{c}32.76 \\
(8.66)\end{array}$ \\
\hline Firm Age (Years) & $\begin{array}{l}12.23 \\
(8.93)\end{array}$ & $\begin{array}{c}8.52 \\
(2.61)\end{array}$ & $\begin{array}{l}10.88 \\
(6.57)\end{array}$ & $\begin{array}{c}9.58 \\
(1.8)\end{array}$ & $\begin{array}{c}13.62 \\
(10.28)\end{array}$ & $\begin{array}{c}12.40 \\
(9.38)\end{array}$ \\
\hline \multicolumn{7}{|l|}{ Liquidation Value } \\
\hline Lease Maturity (Mo.) & $\begin{array}{c}51.51 \\
(35.28)\end{array}$ & $\begin{array}{c}39.03 \\
(6.04)\end{array}$ & $\begin{array}{l}6.00 \\
(.)\end{array}$ & $\begin{array}{l}0.03 \\
(.)\end{array}$ & $\begin{array}{c}74.86 \\
(32.03)\end{array}$ & $\begin{array}{c}57.01 \\
(19.83)\end{array}$ \\
\hline Recovery Index (\%) & $\begin{array}{c}61.58 \\
(4.26)\end{array}$ & $\begin{array}{r}60.51 \\
(.03)\end{array}$ & $\begin{array}{c}69.82 \\
(1.61)\end{array}$ & $\begin{array}{r}51.53 \\
(.05)\end{array}$ & $\begin{array}{r}59.79 \\
(.12)\end{array}$ & $\begin{array}{r}60.97 \\
\quad(.17)\end{array}$ \\
\hline
\end{tabular}

Entrenchment \& Governance Variables

\section{Entrenchment}

$\begin{array}{lcccccc}\text { CEO Tenure } & 95.31 & 97.23 & 88.25 & 79.93 & 101.03 & 93.74 \\ & (75.66) & (75.41) & (80.54) & (53.86) & (52.35) & (97.68) \\ \text { CEO/COB Indicator } & 0.46 & 0.27 & 0.65 & 0.50 & 0.52 & 0.31 \\ & . .5) & (.46) & (.48) & (.52) & (.5) & (.46) \\ \text { MD Charter } & 0.65 & 0.86 & 0.55 & 0.29 & 13.62 & 0.86 \\ & (.48) & (.35) & (.5) & (.47) & (10.28) & (.35) \\ \text { Poison Pill Indicator } & 0.36 & 0.27 & 0.16 & 0.21 & 0.46 & 0.37 \\ & (.48) & (.46) & (.37) & (.43) & (.5) & (.48) \\ \text { Excess Share Plan Ind. } & 0.39 & 0.18 & 0.31 & 0.50 & 0.24 & 0.65 \\ & (.49) & (.39) & (.47) & (.52) & (.43) & (.48) \\ \text { Alignment } & & & & & & \\ \text { CEO \% Ownership } & 4.85 & 1.51 & 6.25 & 1.19 & 6.67 & 2.96 \\ & (9.18) & (1.04) & (11.19) & (1.19) & (11.92) & (3 .)\end{array}$


Table 3 (continued)

\begin{tabular}{|c|c|c|c|c|c|c|}
\hline Variable & All REITs & Industrial & Residential & Hotel & Retail & Office \\
\hline \multirow[t]{2}{*}{ CEO Ownership $<1 \%$} & 0.25 & 0.41 & 0.24 & 0.36 & 0.17 & 0.32 \\
\hline & $(.43)$ & $(.5)$ & $(.43)$ & $(.5)$ & $(.37)$ & $(.47)$ \\
\hline \multirow[t]{2}{*}{ CEO Ownership $>5 \%$} & 0.22 & 0.00 & 0.22 & 0.00 & 0.29 & 0.22 \\
\hline & $(.41)$ & (.) & $(.42)$ & (.) & $(.45)$ & $(.41)$ \\
\hline \multirow[t]{2}{*}{ CEO Vested Options } & 1.75 & 1.49 & 1.38 & 0.69 & 2.14 & 1.68 \\
\hline & $(2.42)$ & $(.83)$ & $(1.25)$ & $(.75)$ & $(3.51)$ & $(1.32)$ \\
\hline \multirow[t]{2}{*}{ CEO is Founder } & 0.42 & 0.27 & 0.35 & 0.64 & 0.41 & 0.47 \\
\hline & $(.49)$ & $(.46)$ & $(.48)$ & $(.5)$ & $(.49)$ & $(.5)$ \\
\hline \multicolumn{7}{|l|}{ Board Structure } \\
\hline \multirow[t]{2}{*}{ Board Size } & 8.53 & 9.32 & 8.67 & 8.21 & 8.57 & 8.29 \\
\hline & $(2.28)$ & $(1.17)$ & $(2.01)$ & $(1.31)$ & $(2.18)$ & $(2.76)$ \\
\hline \multirow[t]{2}{*}{$\%$ Independent Board } & 61.79 & 59.09 & 67.08 & 58.30 & 62.90 & 58.61 \\
\hline & $(13.87)$ & $(9.7)$ & (11.62) & $(7.95)$ & $(15.88)$ & (12.79) \\
\hline \multirow[t]{2}{*}{ Staggered Board(1=Yes) } & 0.63 & 0.64 & 0.53 & 0.57 & 0.70 & 0.59 \\
\hline & $(.48)$ & $(.49)$ & $(.5)$ & $(.51)$ & $(.46)$ & $(.49)$ \\
\hline No. of Observations & 318 & 22 & 55 & 14 & 126 & 101 \\
\hline Percent of Sample & & $6.92 \%$ & $17.30 \%$ & $4.40 \%$ & $39.62 \%$ & $31.76 \%$ \\
\hline
\end{tabular}

This table presents mean (standard deviation) values for the variables used in this study based on 318 pooled time series cross-sectional observations for REITs over the sample period from 1997 to 2006. Disaggregate evidence by property type is also reported. Leverage is the ratio of total debt to the market value of the firm's assets, where the latter is measured as the book value of total assets plus the difference between market value of equity and book value of equity. Debt Maturity is the valueweighted debt maturity in months. Market-to-Book is the ratio of market value of the firm's assets to book value. Market-to-Book ratio is used as a proxy for growth opportunities. Firm Size is market value of the firm's assets in billions of constant 2006 dollars. We use the natural logarithm of size in our regressions. Market Access is a dummy variable equal to 1 if the REIT has access to the market for public debt and zero otherwise. We determine access by whether the firm has a public debt rating or not. Return on Assets is the ratio of net income to the book value of total assets. Volatility is the time series standard deviation of the first differences of funds from operations per share. Earnings Growth is the ratio of next year's earnings per share less this year's earnings per share to this year's end share price. Asset Maturity is the ratio of real estate investments to the total of depreciation and amortization of real estate investments. Lease Maturity is the value-weighted time until lease expiration in months. Recovery Index is the weighted average recovery rate calculated using the S\&P study of CMBS recoveries by property type and the REIT's property type mix. Industrial is a dummy variable equal to 1 if the REIT's investment focus is industrial properties and zero otherwise. Other property type indicators are defined similarly. CEO tenure is the number of months from the appointment date. CEO/COB indicator is a dummy variable taking a value of 1 if CEOs also hold the position of Chairman of the Board (CEO/ COB duality) and zero otherwise. MD Charter is a dummy variable taking a value of 1 if the firm was incorporated in Maryland and zero otherwise. Poison Pill indicator is a dummy variable taking a value of one if the firm has a poison pill plan in place and zero otherwise. Excess Share Plan indicator is a dummy variable taking a value of one if the firm has an excess share plan in place and zero otherwise. CEO \% Ownership is the percentage of shares outstanding owned by the CEO. CEO ownership $<1 \%$ (ownership $>5 \%$ ) is an indicator that takes on a value of one if the CEO owns less (more) than one percent of the outstanding. CEO vested option holdings are total vested options owned by the CEO as a percentage of shares outstanding. CEO is Founder is an indicator taking a value of 1 if the CEO is the founder and zero otherwise. Boar size is the number of the members of the board. \% Independent Board is the percentage of the board members who are independent. Staggered Board is an indicator taking a value of 1 if the board is staggered and zero otherwise 
had a poison pill plan and/or an excess share plan in effect at the time of the observation. ${ }^{40}$ On average, the CEOs in our sample owned $4.85 \%$ of the outstanding stock and held vested options to purchase an additional $1.75 \%$ of the shares. Both of these numbers are significantly larger than those reported by Berger et al. (1997) for industrial firms $(2.7 \%$ stock ownership and vested options to purchase an additional .2\%).

The average size of a REIT's board of directors was 8.5 members, significantly smaller than the twelve members reported by Berger et al. (1997), but the fraction of independent members $(62 \%)$ is quite similar to that in the Berger sample. Roughly two-thirds of the firms have a staggered board.

\section{Results}

We estimated two different model specifications using the different measures of asset liquidation value-lease maturity and the recovery index. The results are presented in Tables 4 and 5. Although our discussion focuses primarily on the governance variables, we also review the major findings related to the financial variables and asset liquidation value proxies.

First, as predicted by Barclay et al. (2003), the signs of the estimated coefficients on both of the endogenous variables in both specifications are negative, consistent with the argument that short maturity debt and low leverage are substitutes. Barclay et al. (2003) argue that because either lower leverage or the use of short-maturity debt can be used to control the underinvestment problem, these two mechanisms should be viewed as substitutes. In both specifications the coefficient on maturity in the leverage equation is negative and significant at the $5 \%$ level or better. The signs on leverage in the maturity equation are negative but not significant.

As expected, growth opportunities, as measured by the ratio of market value to book value have a significant negative sign in the leverage equation of both specifications. The coefficient of market-to-book in the maturity equation is not significant. Firm size, a proxy for firm quality, is negatively related to leverage (consistent with Diamond 1991) and maturity in both specifications, but we see no evidence of the U-shaped maturity effect in our sample. We also find support for Myers' (1984) pecking order prediction that highly profitable firms will use less leverage. Both cash flow volatility and asset maturity have the expected positive relationship with debt maturity choice. The estimated positive effect of volatility on debt maturity is consistent with the prediction that firms with volatile cash flows will try to reduce liquidity risk by locking in longer-term debt in good years. The positive relationship between asset maturity and debt maturity is consistent with an effort to limit risk by matching the asset and debt maturities.

Overall, the estimated coefficients on the financial variables are consistent with those reported by Giambona et al. (2008) and do not conflict with any of the standard hypotheses. As might be expected in a small homogeneous sample, certain variables (e.g., firm age and market access) are not significant in our specifications.

\footnotetext{
$\overline{{ }^{40} \text { Only } 10 \% \text { of the observations }}$ had both a poison pill plan and an excess share plan in effect at the observatiuon date. The correlation between these two indicators is .15.
} 


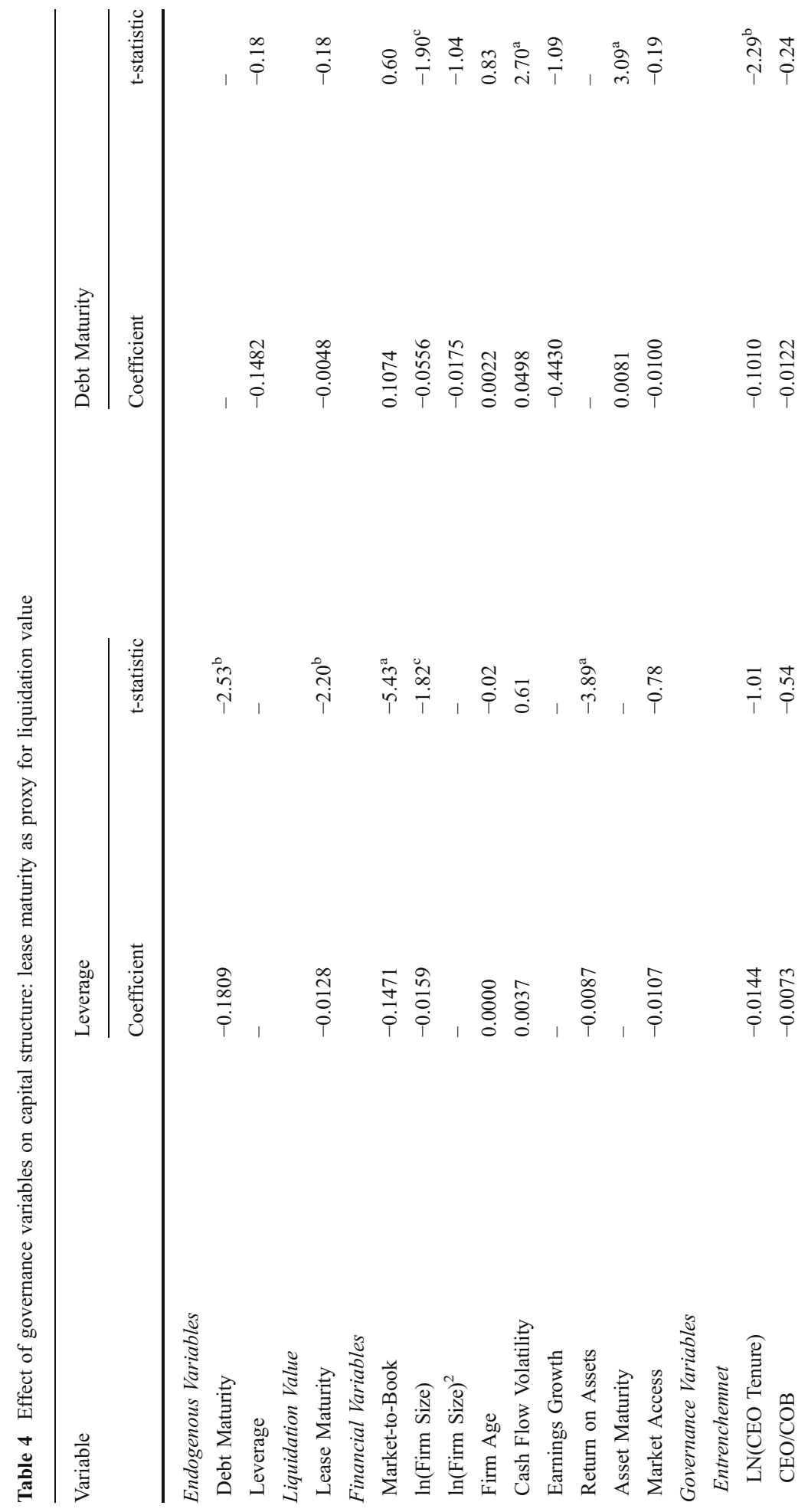




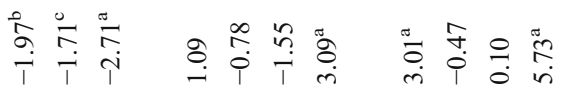

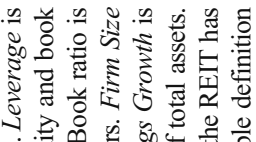

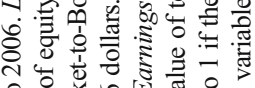

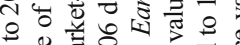

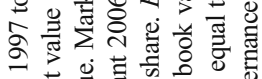

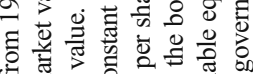

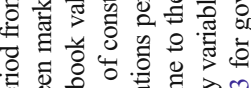

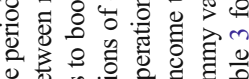

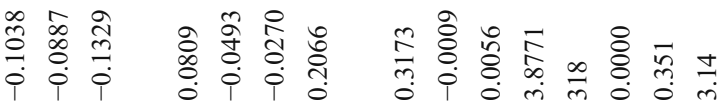

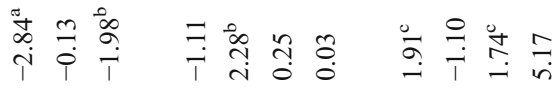

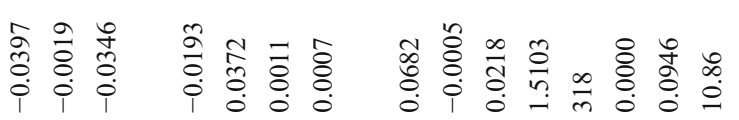

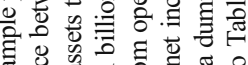

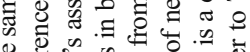

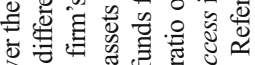

वे

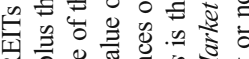

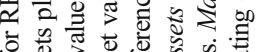

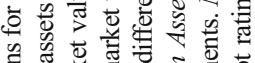

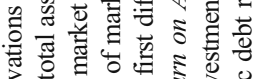

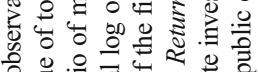

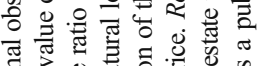

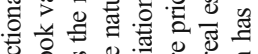

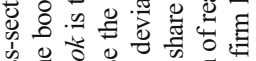

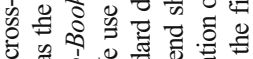

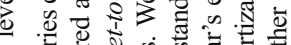

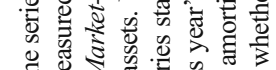

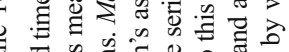

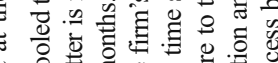

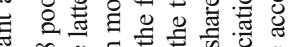

$\infty 0 . \equiv$ क क

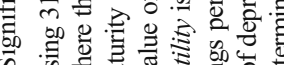

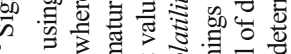

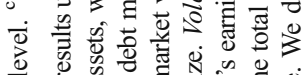

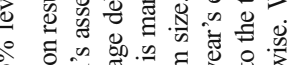

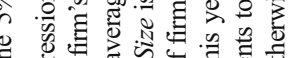

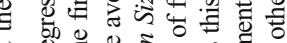

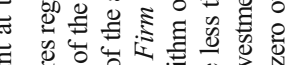

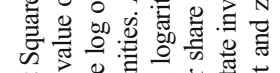

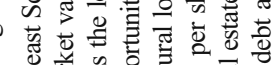

ब

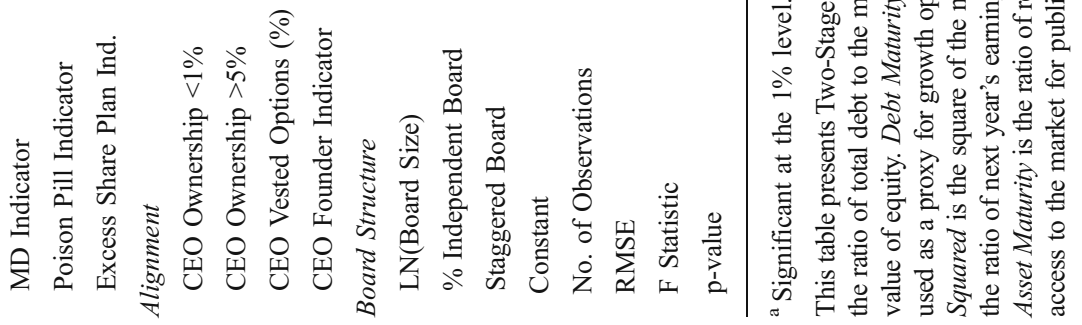




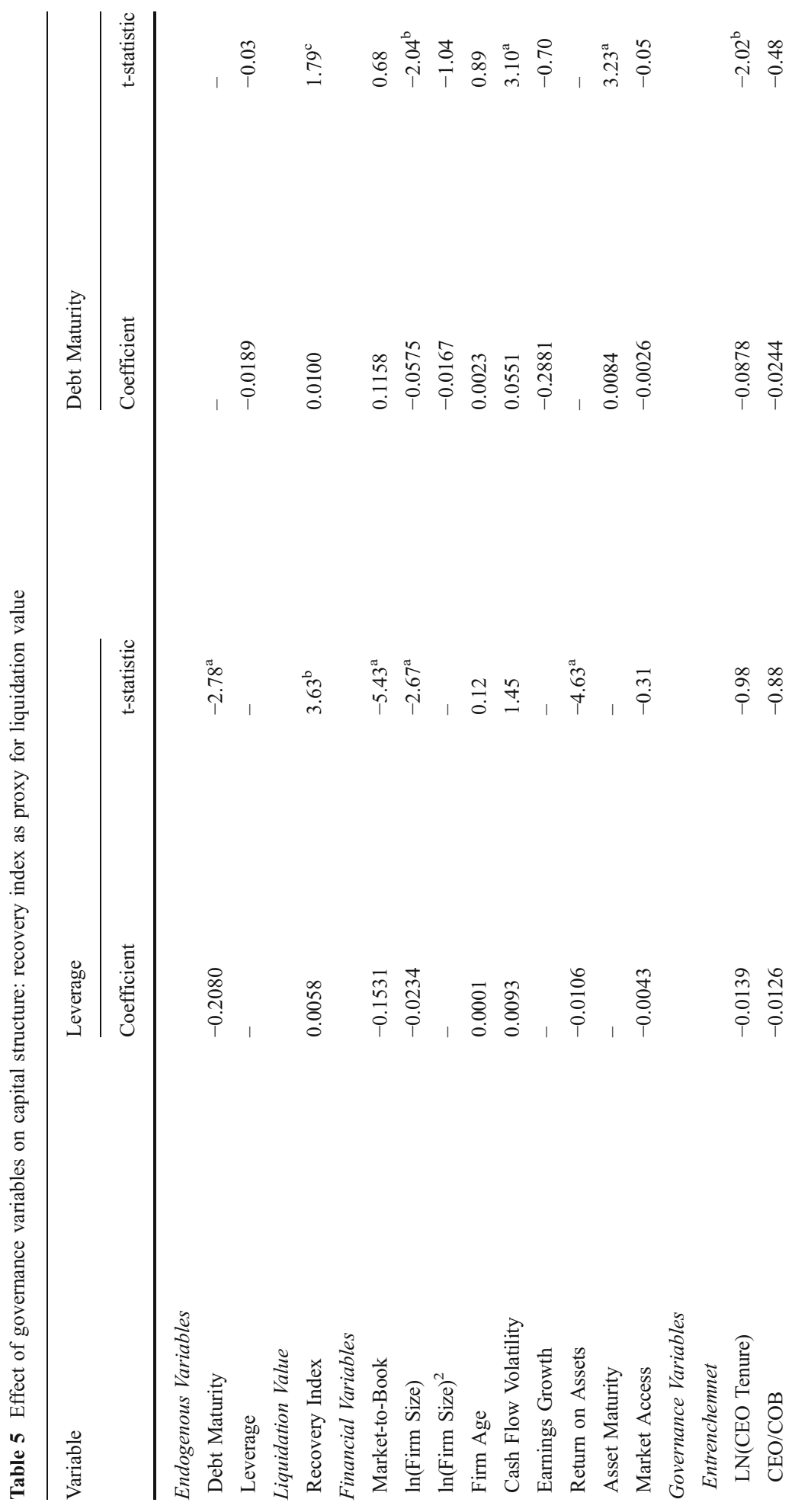




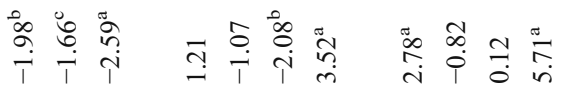

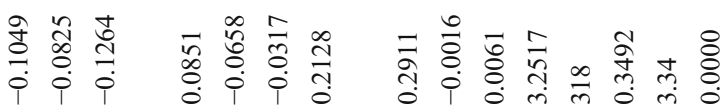

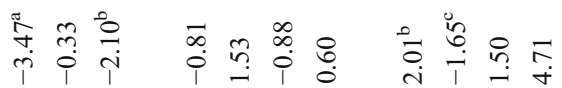

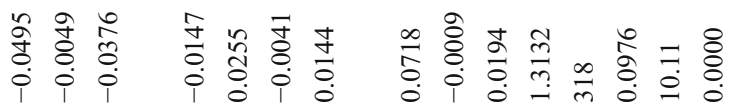

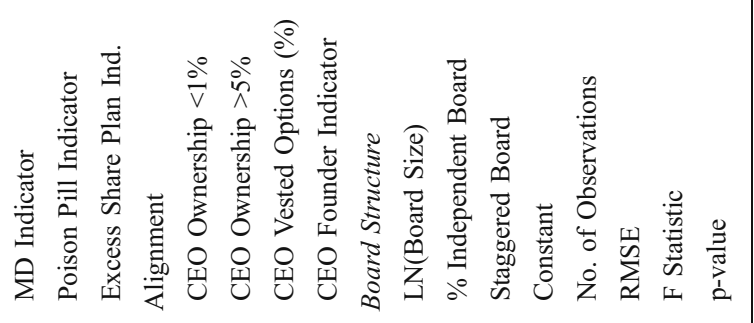

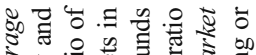

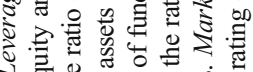

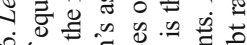

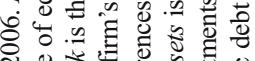

1

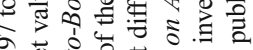

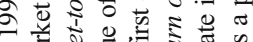

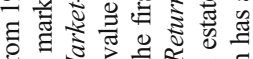

记

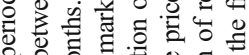

o

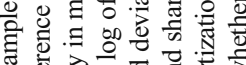

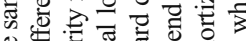

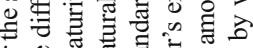

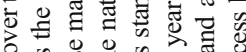

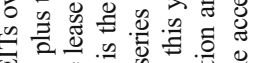

可

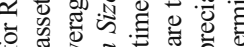

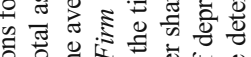

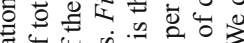

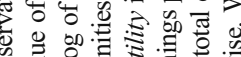

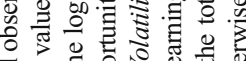

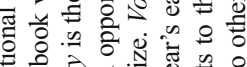

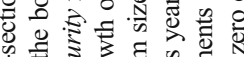

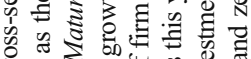

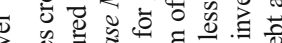

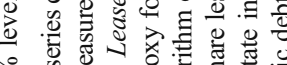

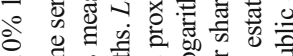

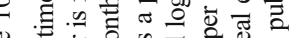

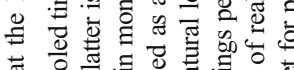

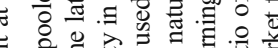

要

竞

些 3

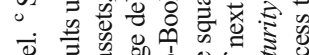

造

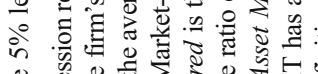

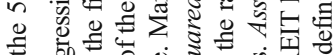

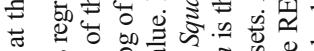

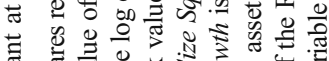

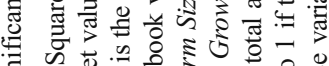

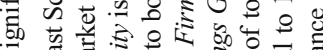

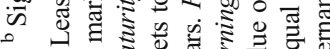

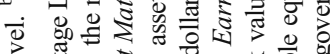

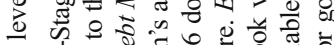

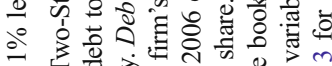

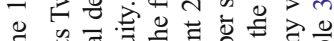

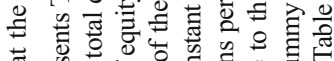

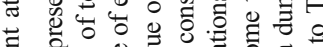

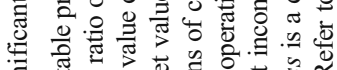

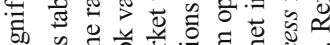

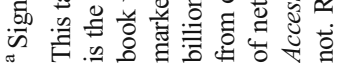


Our results with respect to the proxies for liquidation value confirm the findings reported by Giambona et al. (2008). Firms with assets that have high liquidation value or are more readily redeployed to other uses tend to use more leverage and longer maturity debt than do firms with assets that are less liquid. For example, the coefficients on lease maturity are negative for both equations reported in Table 4, consistent with the view that long leases reduce an owner's ability to redeploy the asset. In Table 5, the coefficients on the recovery index are both positive, reflecting the fact that when a firm's assets retain a greater percentage of their value in financial distress, the firm can increase both leverage and debt maturity.

Turning now to the governance variables that are our primary focus, we begin by looking at the five measures of entrenchment. Taken as a group and considering all four estimated models reported in Tables 4 and 5, twelve of the twenty estimated coefficients are statistically significant with the predicted signs. The remaining coefficients all have the predicted sign but are not estimated precisely enough to achieve statistical significance. Only the indicator for a joint appointment as CEO/ COB duality does not enter any of the estimated equations with a significant coefficient. A test of the null hypothesis that the five coefficients are all zero is strongly rejected for all four equations. The negative signs for both leverage and maturity are consistent with the prediction that entrenched managers choose capital structures that reduce their personal risk and also preserve the flexibility to pursue empire building.

The indicators for a Maryland charter and an excess share plan are the two entrenchment proxies that are statistically significant in the leverage equation. REITs with a Maryland charter have leverage that is $4 \%$ lower than non-Maryland REITs, ceteris paribus. Four of the five entrenchment proxies enter the maturity equations with statistically significant coefficients. Managers of firms with long-tenured CEOs, Maryland charters, poison pill plans or excess share plans choose shorter maturity debt.

Looking next at the proxies for alignment, we find weaker (relative to the entrenchment results) evidence which is, nevertheless, consistent with the predicted positive effects of managerial alignment on both leverage and maturity. Four of the sixteen estimated coefficients are statistically significant, and three of those have the predicted positive sign. The indicator for high CEO ownership (greater than 5\% of outstanding shares) is significant in the leverage equation that uses lease maturity as the proxy for liquidation value, but is not significant in any of the remaining models. One possible explanation for the failure to find a robust ownership effect is the choice of a 5\% threshold for the indicator. As discussed earlier, previous researchers have found evidence of a non-linear, U-shaped, effect of ownership with true alignment only occurring at very high levels of ownership (e.g. greater than $25 \%$ ). Given our small sample, we were unable to explore the possibility of non-linearity at very high levels of ownership with any precision. However, we believe that the indicator for the CEO also being the firm founder may capture a similar phenomenon of strong alignment. In combination, the estimated coefficients on the high ownership indicator and CEO founder indicator are consistent with the argument that better aligned managers will choose higher leverage and longer debt maturities than CEOs whose interest are less aligned with those of the shareholders.

The final group of governance variables comprises the proxies for the effectiveness of the board of directors. Conventional wisdom predicts that larger 
boards are less effective while those with more independent members and staggered board terms will be more effective. The predicted signs were therefore negative for board size and positive for the other two variables. Although our results are not compelling statistically, (six of the twelve coefficients are not statistically significant and three of the six that are statistically significant are only significant at the $10 \%$ level), taken as a whole they are inconsistent with this conventional wisdom. We find a statistically significant positive relationship between large boards and both leverage and debt maturity. One possible explanation for this finding is that most REITs are operating within an effective range of board size. As noted earlier, REIT boards average 8.5 members compared with an average of more than twelve members for industrial firms in the Berger et al. (1997) sample. The argument for the ineffectiveness of large boards rests on the increasing complexity of communication, decision-making and coordination in large groups. Given the small board size of the typical REIT in our sample, even the larger boards may not have reached the tipping point where coordination costs exceed the incremental benefit of adding another member.

\section{Robustness $^{41}$}

The results reported in Tables 4 and 5 are based on 2SLS, which implicitly assumes that the error terms in the two simultaneous equations, conditional on the independent variables, are uncorrelated. Our first robustness check tests that assumption by estimating the models using 3SLS, allowing for the possibility of correlated residuals. The results using 3SLS are essentially unchanged from those reported in Tables 4 and 5 and the significance of the coefficients discussed above is generally somewhat higher. Looking first at the financial variables, maturity, marketto-book, return on assets and firm size remain significant in the two different specifications of the leverage equation, while firm size, cash flow volatility and asset maturity are significant in the maturity equations. The signs of the estimated coefficients on these variables are all unchanged and the levels of significance are generally better in the models estimated using 3SLS. The estimated sign of the coefficient on firm size squared remains negative with 3SLS but the standard error is smaller and so the coefficient is statistically significant with 3SLS. Nevertheless, the results do not support a U-shaped response of maturity to firm size.

Shifting focus to the liquidation value variables, the coefficients, signs and significance levels in all four estimated equations are nearly identical to those reported in Tables 4 and 5 and support the conclusion that the liquidation value of a firm's assets influences the firm's capital structure choices in the manner predicted by Shleifer and Vishny (1992). Finally, using 3SLS, the estimated coefficients on the entrenchment variables remain negative with the same pattern of statistical significance as discussed above. The results for the alignment and board structure variables are also little changed.

\footnotetext{
${ }^{41}$ The results for the various robustness tests discussed in this section are available from the authors upon request.
} 
In summary, using 3SLS instead of 2SLS does not significantly alter any of the conclusions based on the 2SLS results. While the motivation for using 3SLS was a concern that ignoring the possible correlation between the error terms from the two equations could result in overstating the statistical significance of certain coefficients, the statistical significance of the estimated coefficients tends to be higher in these models with 3SLS. We do not report the three stage least squares results as our primary results because, in our opinion, the sample size is too small to rely on the asymptotic properties of three stage least squares.

A significant concern with any empirical work using small samples is the potential influence of a few outliers. As a second robustness check, we "winsorized" the dependent variables, using a threshold value of $5 \%{ }^{42}$ The results from estimating the model with lease maturity as the proxy for liquidation value ${ }^{43}$ are unchanged in terms of the variables that enter the models with significant coefficients and also the signs of those coefficients. In general, t-statistics and significance levels increase after winsorizing the dependent variables. The two exceptions to this general rule were firm size in the leverage equation which went from being marginally significant to being insignificant and cash flow volatility in the maturity equation which went from being significant at the $1 \%$ level in Table 4 to being significant at the $5 \%$ level after winsorizing the endogenous variables. The results for the governance variables are little changed from those discussed in the base model.

Because several previous debt maturity studies have used the percent of debt maturing after 3 years as the measure of debt maturity, we estimated the three specifications using two alternative definitions of debt maturity. The base models of Tables 4 and 5 use the natural logarithm of the REIT's average maturity measured in months. Because REITs use longer maturity debt than do industrial firms, we reestimated our models using both the traditional percent of debt maturing in 3 years or more and the percentage of debt maturing after 5 years. Not surprisingly, the models estimated using the percentage of debt maturing in 3 years or more show fewer statistically significant coefficients than the base mode but generally portray the same basic effects. Among the financial variables, firm size which was marginally significant in both equations reported in Table 4 retains the negative signs but is no longer significant when the model is estimated using the percentage of debt maturing in 3 years or more. Certain other financial variables that had been significant at the $1 \%$ level of significance become significant at the $5 \%$ level. This loss of precision is likely the result of using a noisier measure of debt maturityespecially since the average debt maturity for the REITs being studied is sixty-seven

\footnotetext{
${ }^{42}$ Winsorizing data involves identifying observations of all variables that fall in the upper and lower tails of the observed distribution. The "tails" are defined by the threshold value. For example, with a threshold value of $5 \%$, the two tails are the highest and lowest $5 \%$ of the observations (approximately nine observations for each tail in our sample). The values for each tail observation are rest to equal the fifth or ninety-fifth percentile value. Several recent finance papers (e.g. Flannery and Rangan 2006; Babenko and Vedrashko 2007) have used the "winsorizing" technique to adjust for outliers in their independent variables.

43 To simplify the discussion of the Robustness checks, we generally discuss a single version of the models. In our experience, switching the proxy for liquidation value has little effect on the robustness of the financial and governance variables.
} 
months. Nevertheless, the measures of entrenchment all have the predicted negative coefficients and the preponderance of the alignment variables have positive coefficients, just as was the case in both Tables 4 and 5. Similarly, firms with larger boards and firms with staggered board terms seem to choose higher leverage and longer maturity debt when the models are estimated using this alternative measure of debt maturity.

When we estimate the model using the percentage of debt maturing in more than 5 years, our results are strikingly similar to those of the base model using the estimated average maturity. Two estimated coefficients "move up" one level in terms of statistical significance (CEO ownership of more than 5\% and board size) while three fall one category in significance (Cash flow volatility, the indicator for incorporation in Maryland and the indicator for an Excess Share plan). These small changes in estimated precision are to be expected when a noisier proxy for debt maturity is substituted as the dependent variable. The important result is that the key findings discussed in the Results section robustly persist when we use these alternative measures of maturity.

Given the panel nature of our data, ideally one would control for firm fixed effects. However, given that we have only 318 observations on 51 firms, such an approach is problematic because we are estimating more than forty parameters in the system of two equations. Furthermore, by estimating the models with firm fixed effects (essentially allowing for each firm to have a unique regression intercept) we would lose the ability to estimate the individual effects associated with variables that are constant for a specific REIT. Cash flow volatility and state of incorporation are examples of variables that would have to be excluded because their effect would be indistinguishable from that of the firm constant. In addition, many of the governance variables are very close to being constant across all firms. For example, the poison pill indicator and excess share plan indicator are not strictly constant because different firms adopted their plans at different times and some firms let their plans lapse. Thus mathematically, they can be included in the model, but as a practical matter they are close enough to being constant for most firms and consequently, their effects would be estimated very imprecisely. Because we would have to exclude many of the variables that are the focus of this paper in order to estimate a firm fixed effects model, we do not think this model specification would be useful. ${ }^{44}$

In summary, the robustness tests discussed in this section reinforce the main findings reported in the Results section. Significantly, the negative entrenchment effect on both maturity and leverage persists robustly in the different specifications

\footnotetext{
$\overline{{ }^{44} \text { While most commonly used }}$ when estimating a single equation and not a system of simultaneous equations, estimating the model assuming random firm fixed effects (essentially assuming that the intercept for each observation on the same firm is a random draw from a fixed distribution) is sometimes used to preserve degrees of freedom and avoid excluding all variables that are constant within a firm. We have explored this model specification as well. We used instrumental variables (predicting the leverage in a first stage regression) and then estimated the second stage regression for debt maturity using both fixed and random effects. The resulting Hausman test on the difference between a fixed effects and random effects specification cannot reject the null hypothesis of no systematic difference between fixed and random effects coefficients and suggests that a random effects methodology may not be appropriate. In addition, estimating a random effects model requires the strong assumption that deviations from the mean intercept are uncorrelated with the independent variables. Consequently, we do not discuss the random effects results here.
} 
we have tried. The results with respect to alignment measures - which were weaker in the original results - are somewhat less robust as are the effects associated with the proxies for board effectiveness.

\section{Conclusions}

In this paper, we examined the influence of managerial incentives, traditional managerial monitoring mechanisms and managerial entrenchment on the capital structure of Real Estate Investment Trusts. We find robust evidence that entrenched managers significantly influence the capital structure. Our finding that firms with entrenched managers use less leverage is quite consistent with the standard agency argument that managers acting in their own self-interest will try to minimize the threat of bankruptcy and loss of their prestige and positions. The finding that entrenched managers use shorter maturity debt is consistent with Hart and Moore's (1995) argument that managers who want to preserve the ability to use assets in place to finance overinvestment (negative net present value projects) will prefer short maturity debt.

We argue that the sign of the entrenchment effect on maturity is influenced by the nature of the industry studied. Several previous studies have suggested that managers, acting in their own best interests and not to maximize firm value, would choose long maturity debt because the longer maturity debt would reduce the need to return to the capital markets on a regular basis to refinance maturing debt. By avoiding frequent new debt issues, they would reduce market monitoring and gain flexibility to pursue their own objectives such as excess perquisite consumption. However, the tangible nature of REIT assets, their access to the highly liquid commercial mortgage market and their ability to partially liquidate the firm all serve to minimize the liquidity risk traditionally associated with short maturity debt. Furthermore, as a result of their dividend payout requirement, REITs use higher leverage than industrial firms and REIT managers must go to the debt markets frequently, not only to roll over existing debt but to finance new growth. Thus the incremental cost of using short maturity debt is small for REITs. On the other hand, REIT managers, can benefit from the simple expansion of the firm's assets and the nature of their assets provides a significant opportunity to use assets in place to finance expansion. Hence, for REITs, it is likely that entrenched management will choose shorter maturity debt than would the shareholders if they operated the firm themselves. In a world where managers' and shareholders' interests are not perfectly aligned, Hart and Moore (1995) show that the firm-maximizing choice of the amount of long-maturity debt depends on the balance between the costs and risks of underinvestment and overinvestment. Our finding that entrenched REIT managers prefer short-maturity debt suggests that they value the ability to pursue empire building investments more than they fear more frequent refinancing.

Our results also confirm the offsetting influence of using equity based compensation to align the interests of managers and shareholders. Because REIT managers are exempt from the standard market discipline of hostile takeovers, owners of REITs have implemented significant equity-based compensation. Although estimated less precisely than the entrenchment effects, our evidence 
supports the effectiveness of these programs in at least partially offsetting the entrenchment effects of long CEO tenure and insulation from market forces. Finally, our results confirm the earlier findings of Giambona et al. (2008) that the liquidation value of the firm's assets have significant influence on the firms' capital structure.

Open Access This article is distributed under the terms of the Creative Commons Attribution Noncommercial License which permits any noncommercial use, distribution, and reproduction in any medium, provided the original author(s) and source are credited.

\section{References}

Adams, R., Almeida, H., \& Ferreira, D. (2009). Understanding the relationship between founder-CEOs and firm performance. Journal of Empirical Finance, 16, 136-150.

Allen, P., \& Sirmans, C. F. (1987). An analysis of gains to acquiring firm's shareholders: the special case of REITs. Journal of Financial Economics, 18, 175-184.

Babenko, I., \& A. Vedrashko. (2007). Informativeness of managerial stock ownership and market reaction to stock repurchase announcements. Working Paper ssrn.com/abstract $=891761$.

Barclay, M., Marx, L., \& Smith, C. (2003). The joint determination of leverage and maturity. Journal of Corporate Finance, 9, 149-167.

Benmelech, E. (2005). Asset salability and debt maturity: evidence for 19th century American railroads. Working Paper: University of Chicago.

Benmelech, E., Garmaise, M., \& Moskowitz, T. (2005). Do liquidation values affect financial contracts? evidence from commercial loan contracts and zoning regulation. Quarterly Journal of Economics, 120, 1121-1154.

Benmelech, E. (2006). Managerial entrenchment and debt maturity: Theory and evidence. Harvard University Working Paper.

Berger, P., Ofek, E., \& Yermack, D. (1997). Managerial entrenchment and capital structure decisions. Journal of Finance, 52, 1411-1438.

Billet, M., King, T., \& Mauer, D. (2007). Growth opportunities and the choice of leverage, debt maturity, and covenants. Journal of Finance, 62(2), 697-730.

Campbell, R., Ghosh, C., Petrova, M., \& Sirmans, C. F. (2009). Corporate governance and performance in the market for corporate control, forthcoming, Journal of Real Estate Finance and Economics.

Damodaran, A., \& Liu, C. (1993). Insider trading as a signal of private information. Review of Financial Studies, 6, 79-119.

Datta, S., Iskandar-Datta, M., \& Raman, K. (2005). Managerial stock ownership and the maturity structure of corporate debt. Journal of Finance, 60(5), 2333-2350.

Diamond, D. (1991). Debt maturity structure and liquidity risk. Quarterly Journal of Economics, 106, 709-737.

Diamond, D. (1993). Seniority and maturity of debt contracts. Journal of Financial Economics, 33, 341-368.

Eisenberg, T., Sundgren, S., \& Woods, M. (1998). Larger board size and decreasing firm value in small firms. Journal of Financial Economics, 48, 35-54.

Eisdorfer, A. (2008). Empirical evidence of risk-shifting in financially distressed firms. Journal of Finance, 63(2), 609-637.

Fahlenbrach, R. (2009). Founder-CEOs, Investment decisions, and stock market performance. Journal of Financial and Quantitative Analysis, 44(2), 439-466.

Fama, E. (1980). Agency problems and the theory of the firm. Journal of Political Economy, 88(2), $228-307$.

Faulkender, M., \& Peterson, M. (2006). Does the source of capital affect capital structure? Review of Financial Studies, 19(1), 45-79.

Feng, Z., Ghosh, C., \& Sirmans, C. F. (2005). How important is the board of directors to REIT performance? Journal of Real Estate Portfolio Management, 11(3), 281-294.

Flannery, M. (1986). Asymmetric information and risky debt maturity choice. Journal of Finance, 41(1), 19-37.

Flannery, M., \& Rangan, K. (2006). Partial adjustment toward target capital structures. Journal of Financial Economics, 79(3), 469-506.

Gentry, W., Kemsley, D., \& Mayer, C. (2003). Dividend taxes and share prices: evidence from real estate investment trusts. Journal of Finance, 58(1), 261-282.

Giambona, E., Harding, J., \& Sirmans, C. F. (2008). Explaining the variation in REIT capital structure: the role of asset liquidation value. Real Estate Economics, 36(1), 111-137. 
Graham, J., \& Harvey, C. (2001). The theory and practice of corporate finance: evidence from the field. Journal of Financial Economics, 60, 187-243.

Grossman, S., \& Hart, O. (1982). Corporate financial structure and managerial incentives. In J. McCall (Ed.), The economics of information and uncertainty (pp. 107-140). Chicago: University of Chicago Press.

Harford, J., Li, K., \& Zhao, X. (2007). Corporate boards and the leverage and debt maturity choices. University of Washington Working Paper.

Harris, M., \& Raviv, A. (1988). Capital budgeting and delegation. Journal of Financial Economics, 50, 259-289.

Hart, O., \& Moore, J. (1995). Debt and seniority: an analysis of hard claims in constraining management. American Economic Review, 85, 567-585.

Hartzell, J., Kallberg, J., \& Liu, C. (2005). The role of the underlying real asset market in REIT IPOs. Real Estate Economics, 33(1), 27-50.

Hartzell, J., Kallberg, J., \& Liu, C. (2008). The role of corporate governance in initial public offerings: evidence from real estate investment trusts. Journal of Law and Economics, 51(3), 539-562.

Hartzell, J., Sun, L., \& Titman, S. (2006). The effect of corporate governance on investment: evidence from real estate investment trusts. Real Estate Economics, 34(3), 343-376.

Jaffe, J. (1991). Taxes and the capital structure of partnerships, REITs, and related entities. Journal of Finance, 46, 401-407.

Jensen, M. (1993). The modern industrial revolution, exit and the failure of internal control systems. Journal of Finance, 48(3), 831-880.

Jensen, M., \& Meckling, W. (1976). Theory of the firm: managerial behavior, agency costs and ownership structure. Journal of Financial Economics, 3, 305-360.

Jiraporn, P., \& Kitsabunnarat, P. (2008). Debt maturity structure, shareholder rights, and corporate governance. Journal of Applied Corporate Finance, 17(2), 82-96.

Johnson, S. (2003). Debt maturity and the effects of growth opportunities and liquidity risk on leverage. Review of Financial Studies, 16, 209-236.

Ling, D., \& Ryngaert, M. (1997). Valuation uncertainty, institutional involvement and the underpricing of IPOs: the case of REITs. Journal of Financial Economics, 43(3), 433-456.

Lipton, M., \& Lorsch, J. (1992). A modest proposal for improved corporate governance. Business Lawyer, 48(1), 59-77.

Mak, Y. \& Y. Kusnadi. (2004). Size really matters: Further evidence on the negative relationship between board size and firm value. NUS Business School Working Paper. Available at SSRN: http://ssrn.com/ abstract $=303505$

Marchica, M. (2005). Debt maturity and the characteristics of ownership structure: An empirical investigation of UK firms. Discussion Paper in Economics. University of York.

Masulis, R., Wang, C., \& Xie, F. (2007). Corporate governance and acquirer returns. Journal of Finance, 62(4), 1851-1889.

Myers, S. (1977). Determinants of corporate borrowing. Journal of Financial Economics, 5, 147-175.

Myers, S. (1984). The capital structure puzzle. Journal of Finance, 39, 575-592.

Myers, S. (1993). Still searching for optimal capital structure. Journal of Applied Corporate Finance, 6(1), 4-15.

Rose, M. (2009). Heterogeneous impacts of staggered boards by ownership concentration. Journal of Corporate Finance, 15(2), 113-128.

Shleifer, A., \& Vishny, R. (1992). Liquidation values and debt capacity: a market equilibrium approach. Journal of Finance, 47, 1343-1366.

Shilling, J., \& Howe, J. (1988). Capital structure theory and REIT security offerings. Journal of Finance, 46, 983-993.

Standard and Poor's. (2005). Defaults and losses of standard \& poor's rated U.S. commercial mortgage loans: Year-End 2004.

Stiglitz, J., \& Weiss, A. (1981). Credit rationing in markets with imperfect information. American Economic Review, 71(3), 393-410.

Stohs, M., \& Mauer, D. (1996). The determinants of corporate debt maturity structure. Journal of Business, 69, 279-312.

Stulz, R. (1988). Managerial control of voting rights. Journal of Financial Economics, 20, $25-54$.

Stulz, R. (1990). Managerial discretion and optimal financing policies. Journal of Financial Economics, $26,3-27$.

Wang, K., Chan, S., \& Gau, G. (1992). Initial public offerings of equity securities: anomalous evidence using REITs. Journal of Financial Economics, 31(3), 381-410.

Wilcox, J. (2002). Two cheers for staggered boards. Corporate Governance, 10, 1-5. 